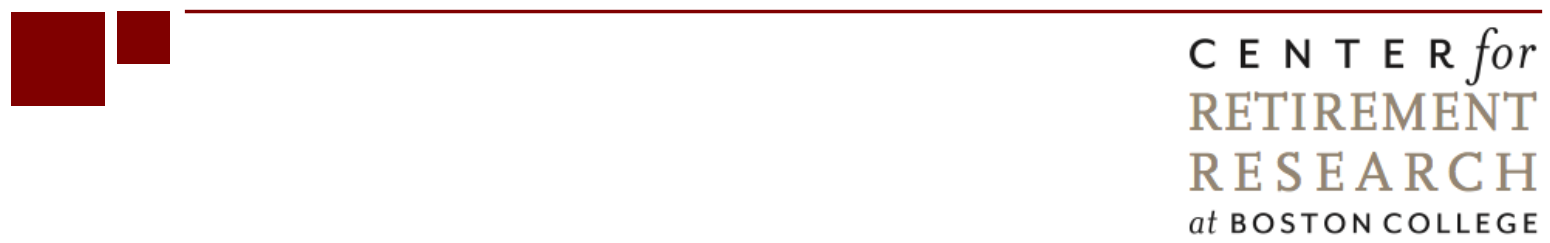

\title{
ADDING EMPLOYER CONTRIBUTIONS TO HEALTH INSURANCE TO SOCIAL SECURITY'S EARNINGS AND TAX BASE
}

\author{
Karen E. Smith and Eric Toder \\ CRR WP 2014-3 \\ Submitted: January 2014 \\ Released: April 2014
Center for Retirement Research at Boston College
Hovey House
140 Commonwealth Avenue
Chestnut Hill, MA 02467
Tel: 617-552-1762 Fax: 617-552-0191
http://crr.bc.edu

Karen E. Smith is a senior fellow at the Urban Institute. Eric Toder is a co-director of the UrbanBrookings Tax Policy Center and a fellow at the Urban Institute. The research reported herein was pursuant to a grant from the U.S. Social Security Administration (SSA), funded as part of the Retirement Research Consortium (RRC). The findings and conclusions expressed are solely those of the authors and do not represent the views of SSA, any agency of the federal government, the RRC, the Urban Institute, the Urban-Brookings Tax Policy Center, or Boston College. The authors are grateful for the comments from Jeffrey Brown, Jim Nunns, and Janet Holtzblatt on earlier versions of this paper. The authors thank Stephen C. Goss and David Pattison for assistance with the AWI calculations. The authors also thank Barbara A. Butrica and Surachai Khitatrakun for assistance with the methods used to project health insurance premiums and Gordon Mermin who helped validate the model projections.

(C) 2014, Karen E. Smith and Eric Toder. All rights reserved. Short sections of text, not to exceed two paragraphs, may be quoted without explicit permission provided that full credit, including (C) notice, is given to the source. 


\begin{abstract}
About the Center for Retirement Research
The Center for Retirement Research at Boston College, part of a consortium that includes parallel centers at the University of Michigan and the National Bureau of Economic Research, was established in 1998 through a grant from the Social Security Administration. The Center's mission is to produce first-class research and forge a strong link between the academic community and decision-makers in the public and private sectors around an issue of critical importance to the nation's future. To achieve this mission, the Center sponsors a wide variety of research projects, transmits new findings to a broad audience, trains new scholars, and broadens access to valuable data sources.
\end{abstract}

Center for Retirement Research at Boston College

Hovey House

140 Commonwealth Avenue

Chestnut Hill, MA 02467

phone: 617-552-1762 fax: 617-552-0191

e-mail: crr@bc.edu

crr.bc.edu

Affiliated Institutions:

The Brookings Institution

Massachusetts Institute of Technology

Syracuse University

Urban Institute 


\begin{abstract}
The inclusion of employer-sponsored health insurance (ESI) in taxable income would increase income and payroll tax receipts, but would also increase Old Age, Survivors, and Disability Insurance (OASDI) benefits by adding ESI to the OASDI earnings base. This study uses the Urban Institute's DYNASIM model to estimate the effects of including ESI premiums in taxable earnings on the level and distribution by age and income groups of income tax burdens, payroll tax burdens, and OASDI benefits. We find that the increased present value of OASDI benefits from including ESI in the wage base in 2014 offsets about 22 percent of increased income and payroll taxes, 57 percent of increased payroll taxes, and 72 percent of increased OASDI taxes. The overall distributions of taxes and benefits by income group follow the same pattern, with both taxes and benefits increasing as a share of income between the bottom and middle quintiles and then declining as a share of income for higher income taxpayers. But households in the bottom income quintiles receive a net benefit from including ESI in the tax base because their increase in OASDI benefits exceeds their increase in income and payroll taxes. Over a lifetime perspective, all earnings groups experience net tax increases, but workers in the middle of the earnings distribution experience the largest net tax increases as a share of lifetime earnings. Higher benefits offset a larger share of tax increases for lower than for higher income groups.
\end{abstract}




\section{Contents}

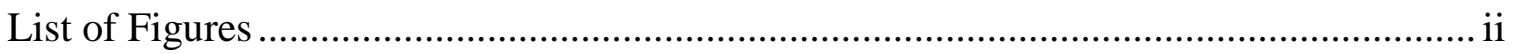

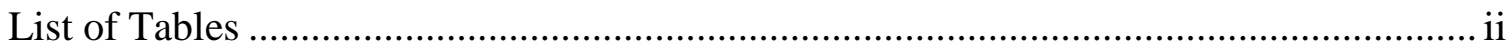

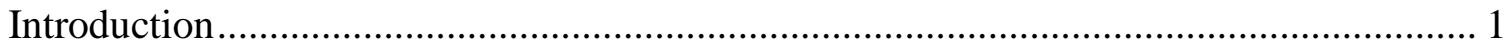

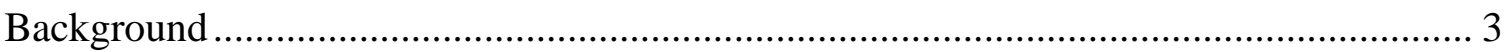

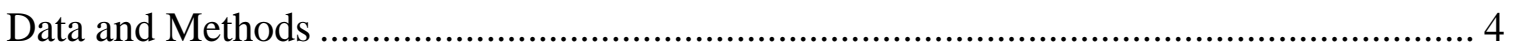

Overview of DYNASIM ................................................................................... 4

Simulating the Effects of Adding ESI to Taxable Earnings ................................... 7

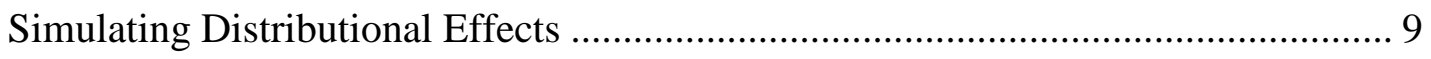

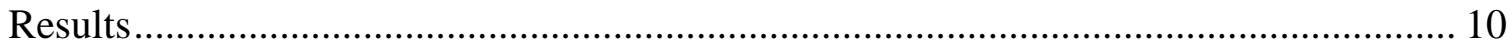

How Broadening the ESI Base Affects Different Workers .................................. 10

Effects of Including ESI in Taxable Earnings on Revenues, Spending, the Federal

Deficit and OASDI Trust Fund Balances .......................................................... 13

Aggregate Effect of Taxable ESI on Taxes and Social Security Benefits................ 14

Comparison with Tax Expenditure Estimates................................................... 18

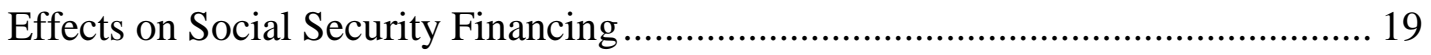

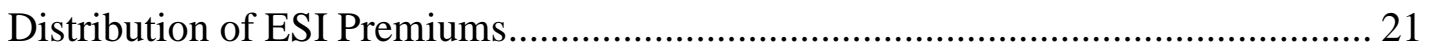

2014 Distribution of Taxes and Present Value of OASDI Benefits ......................... 24

Distributional Effects by Lifetime Earnings and Cohort .................................... 31 
Conclusions

References

39

\section{List of Figures}

Figure 1. Ratio of Alternate AWI to Baseline AWI by Year, 2010-2087 14

Figure 2. Ratio of OASDI Taxes to OASDI Benefits Paid by Year, 2010-2080

Figure 3. Change in Present Discounted Value of Shared Lifetime OASDI Taxes and

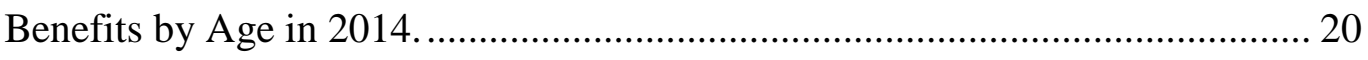

Figure 4. Percent of Tax Units with Earnings and ESI by Income and Age in 2014 ....... 22

Figure 5. Tax Change as a Percent of Income by Income Group and Age in 2014 ........ 26

Figure 6. Tax and Benefit Change as a Percent of Income by Income Group and Age in2014. 28

\section{List of Tables}

Table 1.Example: Tax Calculations for Single Workers at Different Earnings Levels

Table 2. Change in Taxable Income and Tax Receipts from Adding ESI Premiums to Taxable Earnings for Selected Years 2013-2080 (in billions of current dollars)

Table 3. Percent Change in Earnings, Social Security Benefits, and Tax Receipts from Adding ESI Premiums to Taxable Earnings for Selected Years 2013-2080 ..... 17 
Table 4. Comparison of OMB, JCT, and DYNASIM ESI Taxation Estimates, 2014-2018 (in billions of current dollars) 18

Table 5. Distribution of ESI Exclusion by Income Group and Age in 2014 ..... 23

Table 6. Distribution of Tax Changes from eliminating ESI Exclusion by Income Group and Age in 2014 25

Table 7. Distribution of Changes in Present Value of Social Security Benefits from eliminating ESI Exclusion by Income Group and Age in 2014

Table 8. Percent with Increased Benefits or Taxes from Including ESI Premiums in Income Group and Age in 2014

Table 9. Summary: Comparison of Taxes and Benefits by Income and Age in 2014...... 30

Table 10. Ratio of Present Value of ESI Premiums to Present Value of Lifetime Earnings by Lifetime Earnings Groups and Birth Cohort 32

Table 11. Ratio of Present Value of OASDI Tax Increase to Present Value of Lifetime Earnings by Lifetime Earnings Group and Birth Cohort 33

Table 12. Ratio of Present Value of Payroll Tax Increase to Present Value of Lifetime Earnings by Lifetime Earnings Group and Birth Cohort /2

Table 13. Ratio of Present Value of Total Tax (OASDI + HI + Surtax + Federal) Increase to Present Value of Lifetime Earnings by Lifetime Earnings Group and Birth Cohort 34

Table 14. Ratio of Present Value of Increased Social Security Benefits to Present Value of Lifetime Earnings by Lifetime Earnings Group and Birth Cohort....

Table 15. Summary: Ratio of Present Value of Net Tax Increases from Including ESI in Income to Present Value of Lifetime Earnings by Lifetime Earnings Group and Birth Cohort (percent) 36 
Table 16. Ratio of Present Value of Benefits to Total Tax Increases by Lifetime Earnings

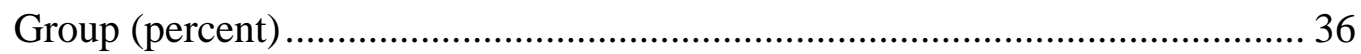




\section{Introduction}

The exclusion of employer-provided health insurance (ESI) from taxable income has long been the largest tax expenditure in the annual lists compiled by the Office of Management and Budget (OMB) and the Joint Committee on Taxation (JCT). OMB (2013) reports the loss in income tax revenue at \$1.310 trillion between fiscal years 2012 and 2017; JCT (2013) estimates the loss at $\$ 941$ billion between 2012 and 2017. ${ }^{1}$ Official tax expenditure estimates include only losses in income tax receipts, but OMB reports in a footnote that the ESI exclusion will also cost the federal government \$701 billion in lost payroll tax receipts between 2012 and 2017.

Phasing out the ESI exclusion has been included in many deficit reduction proposals, including those by the President's Fiscal Commission (2010) and the Bipartisan Policy Center (2010). Eliminating the ESI exclusion has several goals including a) increasing tax revenue, b) improving fairness by providing the same tax treatment for ESI and other forms of employee compensation (including compensation non-covered employees use to purchase private insurance), and c) putting downward pressure on health care spending as purchasers of health insurance make more cost-conscious choices.

The official OMB and JCT estimates for the tax expenditures from the ESI exclusion are incomplete because they do not account for the effects on payroll tax receipts. But OMB does supply a payroll tax estimate in a footnote, which indicates the payroll tax expenditure is more than half the size of the income tax expenditure and could be as much as 70 percent as large if one uses the JCT figures to compute the income tax loss. ${ }^{2}$ However, it is problematic to include

\footnotetext{
${ }^{1}$ OMB estimates of the loss in income tax revenues are larger than the JCT estimates for two main reasons. First, the latest published OMB estimates do not include the effects of the extension of most of the 2001-2010 income tax cuts in the American Tax Relief Act of 2012 (ATRA), enacted on January 1, 2013. Exclusions lose more revenue at the higher marginal tax rates that would have been in effect starting in 2013 had AFTRA not been enacted. Second, OMB assumes that all the additional ESI benefits would raise taxable income, while JCT assumes that taxable benefits would be eligible for the itemized deduction for medical expenses in excess of 10 percent of AGI. Our estimates do include the effects of ATRA and, consistent with JCT, assume that the taxable premiums would be eligible for the itemized deduction for medical expenses.

${ }^{2}$ JCT does not report the loss in payroll tax revenues. But ATRA did not change post-2013 payroll tax rates (the expiration of the temporary payroll cut in effect in 2011 and 2012 that was allowed to occur was already incorporated in baseline receipts projections), and the itemized deduction for medical expenses does not apply to the payroll tax base. So it is safe to assume that had JCT estimated the payroll tax loss they probably would have estimated something very close to the OMB estimate.
} 
the total payroll tax revenue loss in tax expenditures because the same exclusion that reduces payroll tax receipts also reduces accrued Social Security benefits. The magnitude of this benefit offset has not been estimated.

This paper fills this gap. Based on the OMB estimates, including ESI benefits in the payroll tax base would raise about $\$ 125$ billion per year. Much of the added revenue would go into the OASDI trust funds, while the remainder would go to the HI trust fund. But it would also increase workers’ average indexed monthly earnings (AIME) and future Social Security retirement and disability benefits, at least partly offsetting the improvement in OASDI trust fund solvency from the higher revenues. The increased benefits attributable to any single year's inclusion of ESI benefits would be distributed unevenly across workers depending on their age, past and future earnings, past and future marital history, mortality, and the earnings and mortality of current, past, and future spouses. This would in turn produce substantial differences in both increased benefits and incremental benefits per additional dollar of taxes paid among different groups classified by lifetime earnings, retirement income, cohort, race, education level, gender, and marital status.

As population aging and rising health care costs begin to increase federal deficits as a share of gross domestic product (GDP) in the latter part of this decade, policymakers will increasingly look at both tax expenditures and entitlement programs as potential targets for deficit reduction. Broadening the tax base to include ESI benefits, if enacted, could have major effects on both OASDI solvency and retirement income security.

We use the Urban Institute’s Dynamic Simulation of Income Model (DYNASIM3) to simulate the effects of including exempt ESI benefits in taxable income and earnings subject to payroll tax on federal income tax and payroll tax payments and on Social Security retirement and disability benefits through 2086. Based on these simulations, we estimate the effects on federal income and payroll tax receipts, Social Security retirement and disability benefits, OASDI trust fund balances, and the federal budget deficit.

We perform two types of simulations of distributional effects. First, we simulate the oneyear effects of including ESI benefits in taxable earnings in 2014 on income and payroll taxes 
and on the present value of additional OASDI benefits associated with the increase in 2014 OASDI earnings. We perform these calculations for tax units classified by a broad measure of income and by age group. Second, we simulate the effects of a permanent inclusion of ESI in taxable earnings starting in 2014 on the present value of lifetime benefits and taxes for the current working age population, classified by birth cohort (or age), and lifetime earnings quintile. We compute effective marginal tax rates on earnings that depend on the net additional tax burden, after taking account of the effect of an additional dollar of taxable earnings on the present value of future benefits.

\section{Background}

Past research on the ESI exclusion has focused on its effects on health care spending, health insurance coverage, federal receipts, and the distribution of the tax burden (Gruber 2011; Gruber and Lettau 2004; Helms 2008; Toder, Harris, and Lim 2011). The exclusion from the payroll tax base has been mentioned in this research as one source of the revenue loss and has been included in distributional estimates (Gruber, 2011), but without including any offset for the effect on workers’ future Social Security retirement benefits. Harris, Toder, and Lim (2011) estimate the effects of the current law ESI exclusion on the distribution of the tax burden, but include only income taxes, noting that some of the loss in payroll tax revenues from the exclusion "will be recouped by the government in lower Social Security retirement benefits.”

Other research has focused on the distribution of health insurance benefits and the effects of changes in covered earnings on payroll tax collections and future retirement benefits. Burtless and Svaton (2009) impute health benefits to families in the Current Population Survey (CPS) based on Medical Expenditure Panel Survey (MEPS) data to show how including health benefits affects measures of the distribution of income for elderly and non-elderly households. Burtless and Milusheva (2012) estimate the effects of rising health care costs on the distribution of the OASDI wage base and the percentage of workers subject to payroll tax (2012). Butrica, Johnson and Smith (2011) estimate how changes in covered earnings due to the recent recession will affect future retirement benefits. Butrica, Smith, and Steuerle (2006) show how increasing covered wages through additional years of work can increase workers’ retirement security. Favreault (2009) shows how changes in the distribution of earnings can substantially affect the 
size and distribution of future Social Security benefits and Social Security’s long-run financing status. Gustman, Steinmeier and Tabatabai (2012) estimate the effects on retirement benefits of an increase in the cap on covered earnings.

Butrica, Johnson, and Smith (2011) estimate that the recent recession will reduce retirement incomes by an average of 5 percent for adults who were between ages 55 and 59 when the downturn began, largely because it depressed average earnings of the entire workforce. The effect on average earnings, by reducing the indexing factor at age 60 , lowered average indexed monthly earnings (AIME) used to compute retirement benefits even for those workers who themselves did not experience unemployment or a drop in earnings during the recession. In a similar manner, including ESI in the wage base could change average earnings used to compute the wage index (AWI). In that case, changes in health care costs relative to other earnings would affect growth in future Social Security benefits even for workers who never had ESI coverage. ${ }^{3}$

None of these papers address directly how changes in ESI benefits would affect the size and distribution of future retirement benefits. The Office of the Chief Actuary (OCACT) at the Social Security Administration has, however, estimated the effects on total receipts, benefits, and long-run solvency of the proposal by the Bipartisan Policy Center to phase in the taxation of health insurance benefits between 2018 and 2028. Their estimates show that phasing out the ESI exclusion improves Social Security's actuarial balance. This paper provides new estimates of the effects of options to tax ESI benefits on trust fund solvency using the DYNASIM microsimulation model and presents in detail the effects of these proposals on different income groups and cohorts.

\section{Data and Methods}

\section{Overview of DYNASIM}

We use the Urban Institute’s DYNASIM3 model. ${ }^{4}$ DYNASIM3 starts with a self-weighting sample of 103,072 individuals from the 1990 to 1993 panels of the Survey of Income and

\footnotetext{
${ }^{3}$ We discuss below the assumptions we made about how including ESI in the wage base would affect the AWI.

${ }^{4}$ More details about DYNASIM are available in Smith (2012) and Favreault and Smith (2004).
} 
Program Participation (SIPP) of the U.S. Census Bureau. The model ages this starting sample in yearly increments to 2086, using parameters estimated from longitudinal data sources and macroeconomic and demographic assumptions about the future from the Social Security Trustees.

The model integrates many important trends and group-level differences in life course processes, including birth, death, schooling, leaving home, first marriage, remarriage, divorce, disability, work, retirement, and earnings. It projects the major sources of income and wealth annually from age 15 until death, including employment, earnings, Social Security benefits, benefits from employer-sponsored defined benefit (DB) pensions, Supplemental Security Income (SSI), home equity, retirement accounts (defined contribution (DC) plans, individual retirement accounts (IRAs), and Keoghs), and other assets (saving, checking, money market, certificate of deposit (CD), stocks, bonds, equity in businesses, vehicles, and non-home real estate, less unsecured debt).

DYNASIM calculates federal income tax liabilities using an income tax calculator developed by Jon Bakija (Smith et al 2007). The tax calculator uses annual projected tax unit income and assets from the SIPP panels matched to a Statistics of Income (SOI) data file that includes itemized deductions and other variables needed to calculate income tax. The tax calculator assumes current law federal income tax rules, including the provisions in the American Tax Relief Act of 2012 (ATRA). Tax provisions affecting the treatment of Social Security benefits have not changed since 1993, but the share of Social Security benefits included in taxable income is continually increasing under current law in part because the threshold levels for inclusion of benefits in taxable income are not indexed for inflation. Other than the Social Security thresholds, DYNASIM inflates thresholds by projected changes in the CPI through 2023 and by wage growth thereafter. DYNASIM also calculates Social Security coverage and annual payroll taxes using current law payroll tax rates. Only earnings in Social Security covered employment are subject to payroll tax.

DYNASIM also models health insurance coverage and premiums. The premiums include both the workers' and employers’ ESI premiums. DYNASIM's premiums are derived from the Kaiser Family Foundation and Health Research Educational Trust annual employer surveys 
(Kaiser 2012). In 2012, total ESI premiums averaged $\$ 15,745$ for family coverage and $\$ 5,615$ for single coverage. Both health insurance offer and premium projections include important differences by age, education, earnings level, job characteristics, and family characteristics, including the employment status and job characteristics of spouses and the number of dependent children in the family. DYNASIM also projects whether the worker's share of the premium is paid from pre-tax or after-tax dollars. ${ }^{5}$

DYNASIM models the purchase of health insurance at the family level. Families generally select the health insurance plan(s) that generates the lowest out-of-pocket premium cost. However, the probability of selecting a low-cost, high-deductible plan (given a choice) declines as age and family income increase. When both spouses are eligible for employer health insurance, couples with children select the lowest cost family coverage plan and couples without children select either two single plans or one family plan, whichever provides the lowest combined out-of-pocket cost. If only one member of a couple has employer coverage, the couple selects family coverage from that plan.

The model assumes a modest increase in employer-provided insurance beginning in 2015 as a result of the employer mandate included in the Affordable Care Act (2010). We allow families whose ESI premium would exceed 9.5 percent of adjusted gross income to opt out of employer coverage and purchase subsidized insurance through the new health care exchanges. Otherwise, if the family is offered ESI, we assume they take it.

When couples select family coverage, only one worker in the family pays the family premium. When couples select two single plans, each worker pays a single premium. The choice of family or single coverage is important for determining the amount added to payroll taxes because OASDI taxes are capped. Workers whose earnings are above the cap would pay no additional OASDI taxes if ESI premiums were added to the wage base, while workers with earnings below the cap would pay OASDI taxes on all (up to the cap) of the added ESI premium. Medicare (HI) taxes would apply to ESI premiums in all cases. When simulating taxable ESI, we

\footnotetext{
${ }^{5}$ The majority of workers (92 percent) pay their worker share of premiums with pre-tax dollars, though there are large differences in pre-tax coverage by firm size, with large firms more likely than small firms to offer pre-tax payments.
} 
assume no change in the amount of ESI provided or in which spouse (employer) provides the health insurance plan. However, we allow families who itemize to deduct the newly taxable ESI premiums. $^{6}$

Many of DYNASIM's core outcomes are benchmarked to the intermediate assumptions of the Social Security Trustees, including average earnings, employment rates, disability, and mortality. DYNASIM includes detailed Social Security and federal income tax calculators, allowing us to measure changes in Social Security benefits and income tax collections under current law and alternate policies. We assume as a baseline that the current law federal income tax will continue through 2023 and that price-indexed thresholds will grow by wage growth instead of price growth thereafter. This assumption prevents real bracket creep from pushing families into increasingly higher income tax brackets as wage growth outpaces price growth. We assume ESI premiums will increase at the rate of health care spending projected by the Center for Medicare and Medicaid Services (CMS) through 2023 and at the same rate as wages thereafter.

\section{Simulating the Effects of Adding ESI to Taxable Earnings}

We run three simulations. Our baseline simulation is current law, which excludes exempt ESI premiums from the wage base and taxable income. In our first alternate simulation, we add the exempt ESI premiums to earnings in 2014 to calculate the one-year effect on taxes and the increased present value of OASDI benefits attributable to increased taxable earnings in 2014. In our second alternate simulation, we add exempt ESI premiums to earnings in all years beginning in 2014 to calculate the lifetime effects. For workers whose share of premiums is paid in pre-tax dollars, we add the full premium to earnings. For workers whose share of premiums is paid in after-tax dollars, we add only the exempt employer premium to earnings.

Importantly, we assume that employers keep total compensation unchanged when ESI is included in the wage base. We assume employers reduce workers' wages to completely offset

\footnotetext{
${ }^{6}$ The ACA increased the excess medical expense threshold from 7.5 percent to 10 percent of AGI beginning in 2013 for those under age 65 and beginning in 2016 for those 65 and older. Only medical expenses exceeding the AGI threshold are deductible. JCT also assumes that if ESI were made taxable, the newly taxable premium would be deductible; we follow this assumption.
} 
their increased payroll tax liabilities due to inclusion of premiums in the payroll tax base. DYNASIM then simulates workers' contributions to retirement savings accounts and DB pension benefit accruals based on these reduced wages.

We use DYNASIM to calculate the impact of changes in the taxation of ESI on earnings, payroll taxes, federal income taxes, and Social Security benefits. We also calculate its impact on the Average Indexed Monthly Earnings (AIME) measure that the Social Security Administration uses to calculate Social Security benefits, the Social Security taxable maximum, and the bend points in the Social Security benefit formula.

We make an adjustment to the determination of the average wage index (AWI) in 2014. Total ESI premiums are about 10 percent of total wages in 2014, so absent any adjustment, adding ESI premiums to the wage base would significantly increase the AWI for 2014. To determine the AWI in 2014, we follow the adjustment method the Social Security Administration used in 1990 when workers' contributions to retirement accounts (401k, 403b, thrift saving plans, and other tax deferred plans) were added to the wage base (Clingman and Kunkel 1992). This adjustment effectively includes exempt ESI premiums in measured earnings in the two years prior to the policy change and calculates the annual rate of change in earnings in 2014 using this consistently measured earnings definition.

We then construct an index for the growth in wages after 2014 that includes ESI in the wage base in every year. ESI and money wages are projected to grow at different rates between 2014 and 2023. After 2023, we assume ESI and wages grow at the same rate.

We examine how taxing ESI would affect workers' current income, the effective marginal tax rate on their earnings, and future retirement income, with special focus on differences by income quintile and age. We also measure the impact of adding ESI to the wage base on Social Security solvency, calculating the effect on the present value of Social Security benefits and taxes paid to determine how much Social Security benefits rise per dollar of additional taxes paid. 


\section{Simulating Distributional Effects}

We perform two separate sets of simulations. In the first set of simulations, we examine the snapshot effect of including ESI in the tax base in tax year 2014. The results of these simulations are reported in a set of tables with same type of information reported in distributional estimates of the effects of tax policy changes by the U.S. Department of the Treasury, the Congressional Budget Office, the Joint Tax Committee, and the Urban-Brookings Tax Policy Center (TPC). However, we supplement the tax calculations that TPC reports with estimates of the present value of the future OASDI benefits associated with the broadening of the wage base in 2014. For these simulations, we group tax units by quintile of total income and by the age of the tax unit head. The income measure we use is similar to the expanded cash income measure that TPC uses in its distribution tables (Rosenberg 2013). Our income measure includes wage compensation, the employer share of payroll taxes, employer DC contributions, exempt ESI benefits, Social Security benefits, DB pension benefits, interest income, dividend income, rental income, realized capital gains, Supplemental Security Income (SSI), returns on assets within DC plans, and withdrawals from retirement accounts. ${ }^{7}$

In the second set of simulations, we rank workers by their present value of lifetime earnings and compute the change in the present value of benefits and taxes over their lifetime from including ESI in the wage base beginning in 2014. We calculate distributional effects by lifetime earnings quintile for birth cohorts between 1950-59 and 1990-99.

For both sets of simulations, we calculate the present value of benefits and taxes using a 2 percent real discount rate (Steuerle and Rennane 2011).

\footnotetext{
${ }^{7}$ The return on DC balances is calculated as a 2 percent real return on the beginning year annual balance. Actual balances receive a stochastic rate of return centered on the projected mean return for the purpose of projecting the growth in balances over time. While some units are simulated to have negative annual returns in some years, we use the 2 percent real return assumption to rank units and measure income.
} 


\section{Results}

\section{How Broadening the ESI Base Affects Different Workers}

Including ESI in the wage base affects income and payroll taxes differently depending on workers' income. Adding ESI increases payroll taxes of low and middle earners relatively more than for the highest earners. Adding ESI increases federal income taxes more for high earners than for low earners. Single tax filers in tax units with earnings above $\$ 200,000$ ( $\$ 250,000$ for couples) pay a Medicare surtax equal to an additional 0.9 percent of taxable earnings above these thresholds and taxpayers with adjusted gross income above $\$ 200,000$ ( $\$ 250,000$ for couples) pay a 3.8 percent tax on investment income above the thresholds.

We illustrate how taxing ESI affects single earners with only wage income and no itemized deductions at different income levels (table 1). For example, a single worker earning $\$ 10,000$ (top panel) with a \$5,600 ESI premium pays a 6.2 percent Old Age and Survivor Insurance (OASDI) tax, and a 1.45 percent Hospital Insurance (HI) tax on each dollar of earnings. The employer pays an equal amount.

After applying the $\$ 3,950$ personal exemption and $\$ 6,150$ standard deduction, the low earner has no taxable income (column i) and pays no federal income tax but receives a \$354 earned income credit (column k). Her total tax liability of $\$ 1,176$ includes the $\$ 1,530$ in total payroll taxes, assuming the employee bears the burden of the employer portion of the payroll tax in the form of lower wages, less her earned income credit (EIC). Her take-home pay (earnings less worker share of the payroll tax less income tax) is $\$ 9,589$ (column $n$ ).

When including ESI in the wage base, we assume employers hold total pre-tax compensation (including the employer share of payroll taxes) and ESI unchanged. We reduce her wage compensation by $\$ 398$ to account for the higher employer payroll tax 
Table 1. Example Tax Calculations for Single Workers at Different Earnings Levels

\begin{tabular}{|c|c|c|c|c|c|c|c|c|c|c|c|c|c|}
\hline & \multirow{2}{*}{$\begin{array}{c}\text { Total } \\
\text { Compens } \\
\text { ation }\end{array}$} & \multirow{2}{*}{$\begin{array}{c}\text { Wage } \\
\text { Compens } \\
\text { ation }\end{array}$} & \multirow[b]{2}{*}{$\begin{array}{l}\text { Taxable } \\
\text { Earnings }\end{array}$} & \multirow[b]{2}{*}{$\begin{array}{l}\text { Exempt } \\
\text { ESI }\end{array}$} & \multicolumn{2}{|c|}{$\begin{array}{l}\text { Employee Share } \\
\text { of: }\end{array}$} & \multirow{2}{*}{$\begin{array}{l}\text { Medic } \\
\text { are } \\
\text { Surtax }\end{array}$} & \multirow[b]{2}{*}{$\begin{array}{l}\text { Taxable } \\
\text { Income }\end{array}$} & \multirow{2}{*}{$\begin{array}{l}\text { Marginal } \\
\text { Income } \\
\text { Tax Rate } \\
(\%)\end{array}$} & \multirow{2}{*}{$\begin{array}{l}\text { Federal } \\
\text { Income } \\
\text { Tax }\end{array}$} & \multirow[b]{2}{*}{$\begin{array}{l}\text { Total } \\
\text { Tax }^{1}\end{array}$} & \multirow{2}{*}{$\begin{array}{c}\text { Total } \\
\text { Tax } \\
\text { Rate }^{2} \\
(\%)\end{array}$} & \multirow{2}{*}{$\begin{array}{l}\text { Take- } \\
\text { home } \\
\text { Pay }^{3}\end{array}$} \\
\hline & & & & & $\begin{array}{c}\text { OASDI } \\
\text { tax }\end{array}$ & HI tax & & & & & & & \\
\hline & (a) & (b) & (c ) & (d) & (e ) & (g) & (h) & (i) & (j) & $(\mathrm{k})$ & (l) & $(\mathrm{m})$ & (n) \\
\hline Low Earner & 16,365 & 10,000 & 10,000 & 5,600 & 620 & 145 & 0 & 0 & 0 & -354 & 1,176 & 7.2 & 9,589 \\
\hline Low Earner +ESI & 16,365 & 9,602 & 15,202 & 5,600 & 943 & 220 & 0 & 5,102 & 10 & 510 & 2,836 & 17.3 & 7,929 \\
\hline Change & & -398 & 5,202 & 0 & 323 & 75 & 0 & 5,102 & 10 & 864 & 1,660 & & $-1,660$ \\
\hline Percent Change & & & 52 & 0 & 52 & 52 & - & - & - & -244 & 141 & & -17 \\
\hline Middle Earner & 57,272 & 48,000 & 48,000 & 5,600 & 2,976 & 696 & 0 & 37,900 & 25 & 5,359 & 12,703 & 22.2 & 38,969 \\
\hline $\begin{array}{l}\text { Middle Earner + } \\
\text { ESI }\end{array}$ & 57272 & 47602 & 53202 & 5600 & 3299 & 771 & 0 & 43102 & 25 & 6659 & 14799 & 258 & 36873 \\
\hline Change & & $\begin{array}{r}4,+302 \\
-398\end{array}$ & 5,202 & 0 & 323 & 75 & 0 & 5,202 & 0 & 1,301 & 2,096 & 25.0 & $-2,096$ \\
\hline Percent Change & & & 11 & 0 & 11 & 11 & - & 14 & 0 & 24 & 17 & & -5 \\
\hline High Earner & 158,998 & 144,000 & 144,000 & 5,600 & 7,310 & 2,088 & 0 & 133,900 & 28 & 30712 & 49,507 & 31.1 & 103,890 \\
\hline High Earner + ESI & 158,998 & 143,920 & 149,520 & 5,600 & 7,310 & 2,168 & 0 & 139,420 & 28 & 32257 & 51,213 & 32.2 & 102,185 \\
\hline Change & & -80 & 5,520 & 0 & 0 & 80 & 0 & 5,520 & 0 & 1,546 & 1,706 & & $-1,706$ \\
\hline Percent Change & & & 4 & 0 & 0 & 4 & - & 4 & 0 & 5 & 3 & & -2 \\
\hline Super Earner & 449,145 & 430,000 & 430,000 & 5,600 & 7,310 & 6,235 & 2,070 & 419,900 & 39.6 & 123,519 & 152,679 & 34.0 & 292,936 \\
\hline Super Earner + ESI & 449,145 & 429,920 & 435,520 & 5,600 & 7,310 & 6,315 & 2,120 & 425,420 & 28 & 125705 & 155,074 & 34.5 & 290,590 \\
\hline Change & & -80 & 5,520 & 0 & 0 & 80 & 50 & 5,520 & -12 & 2,186 & 2,396 & & $-2,346$ \\
\hline Percent Change & & & 1 & 0 & 0 & 1 & 2 & 1 & -29 & 2 & 2 & & -1 \\
\hline
\end{tabular}

Source: Authors' calculations based on estimated 2014 tax parameters.

${ }^{1}$ Total tax includes both the employee and employer share of payroll tax, Medicare surtax, and income tax.

${ }^{2}$ Total tax rate is the total tax divided by total compensation.

${ }^{3}$ Take-home pay is wage compensation less the income tax and worker share of payroll tax. 
liability from including the $\$ 5,600$ ESI premium in taxable earnings. Her taxable earnings increase by $\$ 5,202$, the ESI premium increase less the reduced wages (column c). Her worker payroll taxes increase by $\$ 398$ and her federal income tax increases to $\$ 510$ from the combination of tax on the higher income and the phase-out of the EIC. Her total taxes (column l) increase by $\$ 1,660$ (141 percent) and her take-home pay (column n) declines by $\$ 1,660$ (17 percent).

Calculations are similar for the middle earner $(\$ 48,000)$. The middle earner also pays the full 15.3 percent in combined payroll taxes, but her higher earnings places her in the 25 percent marginal income tax bracket. She pays $\$ 12,703$ in total taxes (22.2 percent of pretax compensation) and has take-home pay of $\$ 38,969$. Including ESI premiums in taxable earnings increases her total tax by $\$ 2,096$ (17 percent) and reduces her take-home pay by 5 percent.

The high earner $(\$ 144,000)$ has earnings above the Social Security (OASDI) earnings cap. The Medicare (HI) tax is uncapped. The high earner pays $\$ 18,796$ in payroll tax and pays $\$ 30,712$ in federal income tax for a total tax liability of $\$ 49,507$. Her total tax is 31.1 percent of her pre-tax compensation and her take-home pay is $\$ 103,890$. Adding the $\$ 5,600$ ESI premium to taxable income does not increase her OASDI tax liability because her earnings are already above the cap, but she does pay additional $\mathrm{HI}$ tax. We reduce her wage compensation by the $\$ 80$ of additional employer $\mathrm{HI}$ tax. She pays $\$ 80$ of additional $\mathrm{HI}$ tax and $\$ 1,546$ of additional federal income tax. Her take-home pay falls by $\$ 1,706$ (2 percent). Despite paying a higher marginal income tax rate, the high-earner has a smaller total tax change than the middle earner whose earnings with ESI included remains below the cap. Calculations are similar for the super high earner $(\$ 430,000)$, but this worker has income above the Medicare surtax threshold and pays a marginal income tax rate of 39.6 percent plus an additional $\$ 2,070$ (0.9 percent) on her $\$ 230,000$ of earnings above the $\$ 200,000$ threshold for the surtax. Including ESI in taxable wages increases her total tax liability by $\$ 2,396$ and reduces her take-home pay by $\$ 2,346$ (1 percent). 


\section{Effects of Including ESI in Taxable Earnings on Revenues, Spending, the Federal}

\section{Deficit and OASDI Trust Fund Balances}

Historically, health care costs have been growing faster than earnings. This means that in the past an AWI that included ESI premiums would have grown faster than the current AWI, which excludes this fringe benefit. The Center for Medicare and Medicaid Services (CMS) projects that health costs will continue to grow faster than wages over the next few years, but will eventually grow less rapidly than wages, reflecting downward pressure on health costs resulting from a reduction in uncompensated care as health insurance coverage rises under the ACA. Changes in age, employment rates, marital status, and family size also change the ratio of ESI premiums to earnings over time.

Even after using ESI-adjusted earnings to calculate the $2014 \mathrm{AWI}^{8}$, calculated average earnings per worker including ESI still increases in the alternative simulation with ESI included in earnings relative to the current law baseline (figure 1). The 2 percent faster growth in ESI premiums relative to wages in 2014 partly reflects changes in ESI coverage that results from the ACA and partly reflects CMS assumed increases in the growth in health costs compared with the growth in money wages. Over time, however, the projected growth rate in ESI spending falls below the growth in money wages. DYNASIM then projects that the two growth rates become equal after 2023. DYNASIM also projects shifts in employment, family size, and firm characteristics as the population ages. Combining these factors, the alternate AWI generally falls between 2014 and 2050 and then fluctuates between one percent and two percent below baseline AWI after 2050. We use these adjusted AWI factors to calculate Social Security benefits for our simulations of the effects of including ESI benefits in earnings.

\footnotetext{
${ }^{8}$ This means that in calculating the growth in the AWI between 2013 and 2014 (the assumed effective date of the inclusion of ESI in earnings), the 2013 AWI is adjusted upward to the level it would have been if ESI were included in taxable earnings in 2013.
} 
Figure 1. Ratio of Alternate AWI to Baseline AWI by Year, 2010-2087

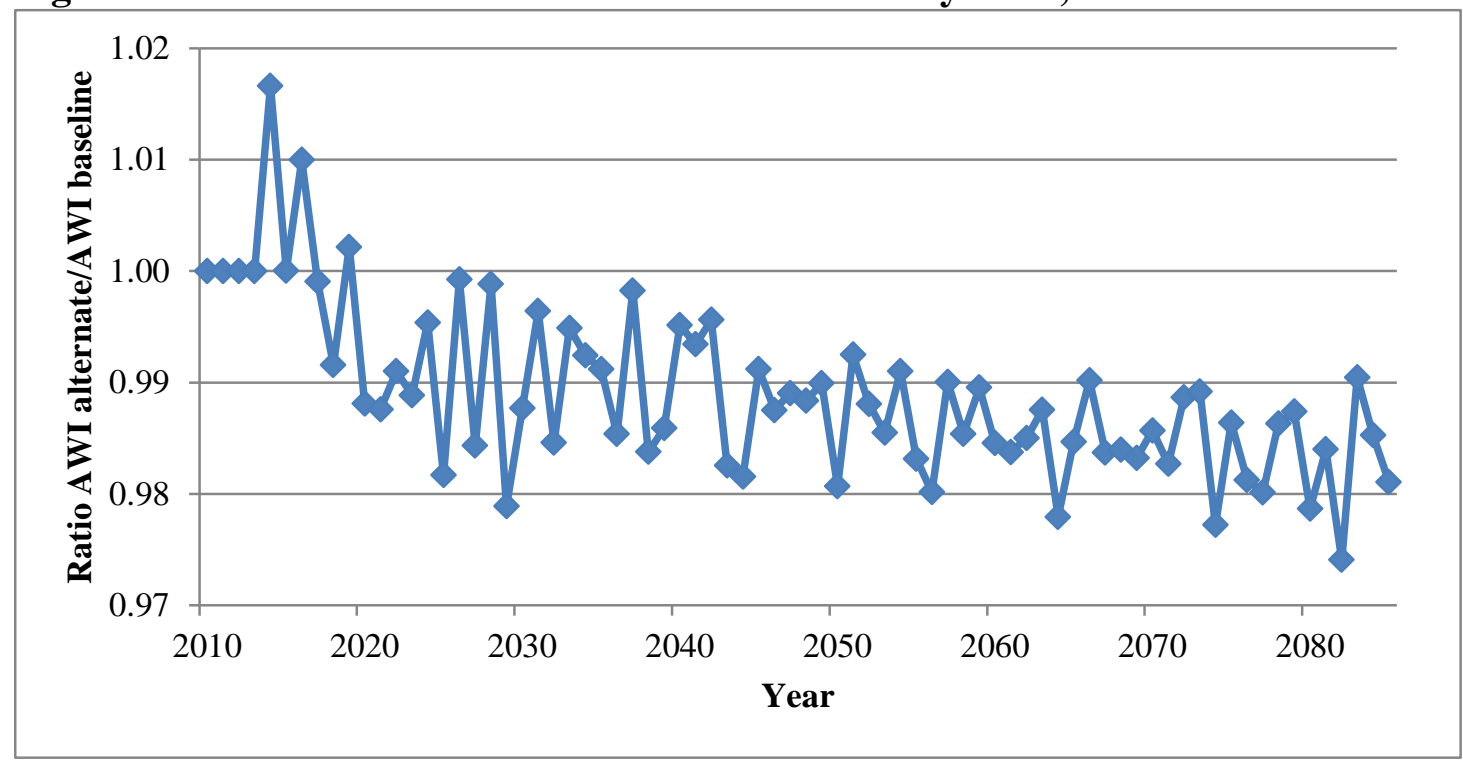

Source: Authors calculations from DYNASIM3.

We use the updated AWI values to index all Social Security benefit parameters for the alternate simulation beginning in 2014. Compared to the baseline simulation, these adjustments generate slightly higher values of adjusted indexed monthly earnings (AIMEs), taxable maximums, bend points, and exempt amounts beginning in 2014, and lower values after 2020, but the differences are small.

\section{Aggregate Effect of Taxable ESI on Taxes and Social Security Benefits}

Adding ESI to reported earnings increases receipts from payroll taxes, the high income Medicare surtax, and federal income taxes (table 2). Outlays for Social Security benefits decline for several years, but then increase by growing amounts after 2020 .

In 2014, taxable earnings increase by $\$ 827$ billion by including the ESI premiums, payroll taxes (OASDI and $\mathrm{HI}$ ) increase by $\$ 103$ billion, and federal income taxes increase by $\$ 157$ billion, but Social Security benefits fall $\$ 4$ billion. The federal budget deficit declines by \$265 billion. 
Table 2. Change in Taxable Income and Tax Receipts from Adding ESI Premiums to Taxable Earnings for Selected Years 2013-2080 (in billions of current dollars)

\begin{tabular}{|c|c|c|c|c|c|c|c|c|c|c|c|c|}
\hline Year & Earnings & $\begin{array}{c}\text { OASDI } \\
\text { Tax }\end{array}$ & $\begin{array}{l}\text { HI } \\
\text { Tax }\end{array}$ & $\begin{array}{l}\text { Payroll } \\
\text { Tax }\end{array}$ & $\begin{array}{l}\text { Medicare } \\
\text { Surtax }\end{array}$ & $\begin{array}{l}\text { Federal } \\
\text { Income } \\
\text { Tax }\end{array}$ & $\begin{array}{c}\text { Social } \\
\text { Security } \\
\text { Benefits }\end{array}$ & $\begin{array}{l}\text { Total } \\
\text { Tax }^{1}\end{array}$ & $\begin{array}{l}\text { Budget } \\
\text { Deficit }^{2}\end{array}$ & $\begin{array}{c}\text { Budget } \\
\text { Deficit } \\
\% \text { of } \\
\text { Earnings }\end{array}$ & $\begin{array}{l}\text { Budget } \\
\text { Deficit \% } \\
\text { of GDP }\end{array}$ & $\begin{array}{c}\text { Cumulative } \\
\text { Budget } \\
\text { Deficit }\end{array}$ \\
\hline 2013 & 0 & 0 & 0 & 0 & 0 & 0 & 0 & 0 & 0 & $0.0 \%$ & $0.0 \%$ & 0 \\
\hline 2014 & 827 & 82 & 22 & 103 & 0 & 157 & -4 & 261 & -265 & $-3.2 \%$ & $-1.6 \%$ & -265 \\
\hline 2015 & 837 & 82 & 22 & 104 & 1 & 161 & -4 & 266 & -269 & $-3.1 \%$ & $-1.5 \%$ & -534 \\
\hline 2016 & 875 & 86 & 23 & 109 & 1 & 170 & -4 & 279 & -283 & $-3.1 \%$ & $-1.5 \%$ & -818 \\
\hline 2017 & 913 & 90 & 24 & 114 & 1 & 177 & -3 & 292 & -295 & $-3.0 \%$ & $-1.5 \%$ & $-1,113$ \\
\hline 2018 & 956 & 94 & 25 & 119 & 1 & 187 & -1 & 307 & -308 & $-3.0 \%$ & $-1.5 \%$ & $-1,420$ \\
\hline 2019 & 994 & 98 & 26 & 124 & 1 & 196 & 0 & 321 & -320 & $-3.0 \%$ & $-1.5 \%$ & $-1,740$ \\
\hline 2020 & 1,042 & 103 & 27 & 130 & 1 & 208 & 2 & 339 & -337 & $-3.0 \%$ & $-1.5 \%$ & $-2,077$ \\
\hline 2025 & 1,292 & 128 & 34 & 161 & 2 & 261 & 10 & 424 & -414 & $-3.0 \%$ & $-1.5 \%$ & $-3,993$ \\
\hline 2030 & 1,588 & 156 & 42 & 198 & 3 & 320 & 19 & 521 & -503 & $-2.9 \%$ & $-1.5 \%$ & $-6,321$ \\
\hline 2035 & 1,951 & 193 & 51 & 244 & 6 & 394 & 36 & 644 & -608 & $-2.8 \%$ & $-1.4 \%$ & $-9,126$ \\
\hline 2040 & 2,377 & 234 & 63 & 297 & 10 & 479 & 62 & 785 & -724 & $-2.7 \%$ & $-1.4 \%$ & $-12,503$ \\
\hline 2045 & 2,956 & 293 & 78 & 371 & 15 & 592 & 102 & 978 & -876 & $-2.6 \%$ & $-1.3 \%$ & $-16,575$ \\
\hline 2050 & 3,628 & 361 & 96 & 457 & 22 & 729 & 163 & 1,208 & $-1,045$ & $-2.5 \%$ & $-1.3 \%$ & $-21,456$ \\
\hline 2055 & 4,450 & 442 & 118 & 560 & 30 & 894 & 246 & 1,485 & $-1,239$ & $-2.4 \%$ & $-1.2 \%$ & $-27,254$ \\
\hline 2060 & 5,451 & 542 & 145 & 687 & 41 & 1,090 & 343 & 1,817 & $-1,474$ & $-2.3 \%$ & $-1.2 \%$ & $-34,121$ \\
\hline 2065 & 6,705 & 675 & 179 & 854 & 53 & 1,348 & 458 & 2,256 & $-1,797$ & $-2.3 \%$ & $-1.1 \%$ & $-42,451$ \\
\hline 2070 & 8,278 & 830 & 221 & 1,051 & 69 & 1,663 & 593 & 2,783 & $-2,190$ & $-2.3 \%$ & $-1.1 \%$ & $-52,638$ \\
\hline 2075 & 10,210 & 1,030 & 274 & 1,304 & 88 & 2,045 & 747 & 3,437 & $-2,690$ & $-2.3 \%$ & $-1.1 \%$ & $-65,061$ \\
\hline 2080 & 12,539 & 1,264 & 336 & 1,600 & 111 & 2,514 & 926 & 4,225 & $-3,299$ & $-2.2 \%$ & $-1.1 \%$ & $-80,302$ \\
\hline
\end{tabular}

Source: Authors' calculations from DYNASIM3.

Note: Table shows estimated change in billions of nominal dollars. Detail may not add to totals due to rounding.

${ }^{1 /}$ Total tax is the sum of payroll tax, Medicare surtax, and federal income tax.

${ }^{2 /}$ Budget deficit is total tax minus Social Security benefits. 
Total Social Security benefit outlays fall between 2014 and 2018 because of the retirement earnings test (RET). ${ }^{9}$ Working beneficiaries between ages 62 and the full retirement age (now age 66) have benefits reduced if their earnings are above an exempt amount. When ESI is added to taxable earnings, the RET reduces payable Social Security benefits. Some new beneficiaries see an increase in benefits with the addition of ESI to the earnings used to calculate their AIME, but these additions when averaged over the top 35 years of indexed earnings used to calculate AIME are relatively small. In aggregate, the reduction in Social Security benefits from the RET is greater than the increase in benefits from higher AIMEs. After 2018, as the years in which new beneficiaries have received higher taxable wages increases, higher Social Security benefit amounts generated from including these higher earnings in the AIME calculation more than offset the losses in benefits from the RET among working beneficiaries between ages 62 and the normal retirement age.

After claiming begins, Social Security benefits increase by annual cost of living adjustments. Including ESI in the wage base in 2014 has no effect on benefits received by current beneficiaries with no earnings. Over time, however, an increasing share of Social Security beneficiaries will have benefits determined using earnings that include the ESI. The result is a very nonlinear growth in additional Social Security outlays over time (see table 3). The projected change in annual Social Security benefit outlays increases by 0.1 percent in 2020, 1.8 percent in 2040, and levels off at an annual growth rate of about 4.6 percent by 2070 .

\footnotetext{
${ }^{9}$ Consistent with the RET treatment used during the 1990 wage base expansion, we made no adjustment to the RET earnings thresholds to account for the addition of ESI in the wage base. Increases in the RET thresholds would lower the share of workers with benefits reduced by the RET.
} 
Table 3. Percent Change in Earnings, Social Security Benefits, and Tax Receipts from Adding ESI Premiums to Taxable Earnings for Selected Years 2013-2080

\begin{tabular}{|c|c|c|c|c|c|c|c|c|c|c|}
\hline Year & Earnings & $\begin{array}{c}\text { OASDI } \\
\text { Tax }\end{array}$ & HI Tax & Payroll Tax & $\begin{array}{l}\text { Medicare } \\
\text { Surtax }\end{array}$ & $\begin{array}{c}\text { Federal } \\
\text { Income Tax }\end{array}$ & $\begin{array}{c}\text { Social } \\
\text { Security } \\
\text { Benefits }\end{array}$ & $\begin{array}{c}\text { Total } \\
\text { Tax }\end{array}$ & $\begin{array}{c}\text { Tax on } \\
\text { Tier1 } \\
\text { Benefits }\end{array}$ & $\begin{array}{c}\text { Tax on } \\
\text { Tier2 } \\
\text { Benefits }\end{array}$ \\
\hline 2013 & 0.0 & 0.0 & 0.0 & 0.0 & 0.0 & 0.0 & 0.0 & 0.0 & 0.0 & 0 \\
\hline 2014 & 10.1 & 10.5 & 9.9 & 10.3 & 3.1 & 13.8 & -0.5 & 12.1 & 3.7 & 3.9 \\
\hline 2015 & 9.7 & 10.0 & 9.5 & 9.9 & 3.6 & 12.8 & -0.4 & 11.4 & 3.5 & 3.6 \\
\hline 2016 & 9.5 & 9.8 & 9.3 & 9.7 & 3.7 & 12.6 & -0.4 & 11.2 & 3.4 & 3.5 \\
\hline 2017 & 9.4 & 9.7 & 9.2 & 9.6 & 4.1 & 12.3 & -0.3 & 11.0 & 3.2 & 3.4 \\
\hline 2018 & 9.3 & 9.6 & 9.1 & 9.5 & 3.9 & 12.1 & -0.1 & 10.9 & 3.1 & 3.3 \\
\hline 2019 & 9.2 & 9.6 & 9.1 & 9.5 & 4.0 & 11.8 & 0.0 & 10.7 & 3.0 & 3.2 \\
\hline 2020 & 9.2 & 9.6 & 9.1 & 9.5 & 4.2 & 11.9 & 0.1 & 10.8 & 2.9 & 3.1 \\
\hline 2025 & 9.3 & 9.7 & 9.2 & 9.6 & 5.1 & 11.7 & 0.6 & 10.7 & 2.4 & 2.5 \\
\hline 2030 & 9.2 & 9.4 & 9.0 & 9.3 & 6.6 & 11.5 & 0.9 & 10.5 & 2.2 & 2.2 \\
\hline 2035 & 9.1 & 9.4 & 8.9 & 9.3 & 7.1 & 11.1 & 1.3 & 10.3 & 2.0 & 2.1 \\
\hline 2040 & 8.8 & 9.1 & 8.7 & 9.0 & 7.8 & 10.7 & 1.8 & 9.9 & 2.0 & 2.0 \\
\hline 2045 & 8.8 & 9.1 & 8.7 & 9.0 & 8.5 & 10.8 & 2.5 & 10.0 & 2.1 & 2.1 \\
\hline 2050 & 8.8 & 9.1 & 8.7 & 9.0 & 8.7 & 10.7 & 3.2 & 9.9 & 2.1 & 2.1 \\
\hline 2055 & 8.6 & 8.9 & 8.4 & 8.8 & 8.7 & 10.4 & 3.9 & 9.7 & 2.2 & 2.2 \\
\hline 2060 & 8.6 & 8.9 & 8.4 & 8.8 & 8.5 & 10.2 & 4.3 & 9.6 & 2.1 & 2.1 \\
\hline 2065 & 8.6 & 9.0 & 8.5 & 8.9 & 8.5 & 10.3 & 4.5 & 9.6 & 2.1 & 2.1 \\
\hline 2070 & 8.5 & 8.9 & 8.4 & 8.8 & 8.2 & 10.1 & 4.6 & 9.5 & 2.0 & 2.1 \\
\hline 2075 & 8.5 & 8.9 & 8.4 & 8.8 & 7.8 & 10.1 & 4.6 & 9.5 & 2.0 & 2.0 \\
\hline 2080 & 8.5 & 8.8 & 8.3 & 8.7 & 7.6 & 9.8 & 4.5 & 9.3 & 2.0 & 2.0 \\
\hline
\end{tabular}

Source: Authors' calculations from DYNASIM3. 


\section{Comparison with Tax Expenditure Estimates}

DYNASIM's estimates of the additional income tax receipts from eliminating the ESI exclusion are very close to JCT's estimates of the loss in income tax receipts from the ESI exclusion and its estimates of the loss in payroll tax receipts are very close to OMB's estimate of the loss in payroll tax receipts (table 4). (The estimates are not strictly comparable because JCT and OMB report fiscal year figures, while the DYNASIM figures are calendar year estimates.) As discussed above, both DYNASIM and JCT report a lower income tax effect than OMB, reflecting OMB's use of a baseline with higher marginal tax rates and a different assumption between DYNASIM/JCT and OMB regarding the inclusion in the base of the deduction for itemized medical expenses of taxable ESI premiums. The OMB estimate assumes the taxable premiums are not deductible, while JCT and DYNASIM assume taxpayers would be allowed to include ESI premiums in deductible medical expenses on Schedule A. ${ }^{10}$

Table 4. Comparison of OMB, JCT, and DYNASIM ESI Taxation Estimates, 2014-2018 (in billions of current dollars)

\begin{tabular}{ccccccc}
\hline & \multicolumn{2}{c}{ OMB } & \multicolumn{2}{c}{ JCT } & \multicolumn{2}{c}{ DYNASIM } \\
\cline { 2 - 7 } Year & $\begin{array}{c}\text { Federal } \\
\text { Tax }\end{array}$ & $\begin{array}{c}\text { Payroll } \\
\text { Tax }\end{array}$ & $\begin{array}{c}\text { Federal } \\
\text { Tax }\end{array}$ & $\begin{array}{c}\text { Payroll } \\
\text { Tax }\end{array}$ & $\begin{array}{c}\text { Federal } \\
\text { Tax }\end{array}$ & $\begin{array}{c}\text { Payroll } \\
\text { Tax }\end{array}$ \\
\cline { 2 - 7 } 2014 & 183.2 & 107.8 & 153.4 & NA & 156.9 & 103.3 \\
2015 & 202.5 & 111.1 & 164.0 & NA & 160.7 & 104.5 \\
2016 & 202.8 & 112.6 & 172.9 & NA & 169.9 & 109.0 \\
2017 & 224.6 & 116.5 & 183.4 & NA & 177.3 & 114.2 \\
2018 & 239.6 & 122.7 & NA & NA & 186.6 & 119.5 \\
\hline
\end{tabular}

Source: Authors' calculations from DYNASIM3, Office of Management and Budget (2013), Joint Committee on Taxation (2013).

\footnotetext{
10 The Congressional Budget Office (CBO, 2013) has also estimated the ESI tax expenditure, but only for tax year 2013 and before implementation of ACA. CBO's estimated of the total revenue loss is by chance the same as the DYNASIM 2014 estimate (\$260), but they show a higher percentage coming from payroll taxes than DYNASIM. As with OMB and JCT, CBO does not estimate the change in present value of future OASDI outlays.
} 


\section{Effects on Social Security Financing}

OASDI payroll taxes are used to fund Social Security benefits and HI taxes are used to fund part A of Medicare (hospital insurance). A portion of the revenue from including Social Security benefits in AGI also goes to the OASDI trust fund. Figure 2 shows estimated OASDI tax (including income taxation of benefits) to benefit ratios for both the baseline and alternate simulations from 2010 to 2087. When the ratio is above one, OASDI taxes exceed OASDI benefits. When the ratio is below one, benefits exceed taxes. Under current law, OASDI tax-tobenefit ratios are projected to be below one in every year from 2010 to 2080. If ESI were included in taxable wages, estimated OASDI revenue rises faster than Social Security benefits, generating OASDI annual surpluses from 2014 through 2021, but after 2021 Social Security benefits increase more than the payroll taxes and the ratio again falls below one. Taxing ESI premiums would improve Social Security’s financing in every year compared to the baseline, but taxing ESI would

Figure 2. Ratio of OASDI Taxes to OASDI Benefits Paid by Year, 2010-2080

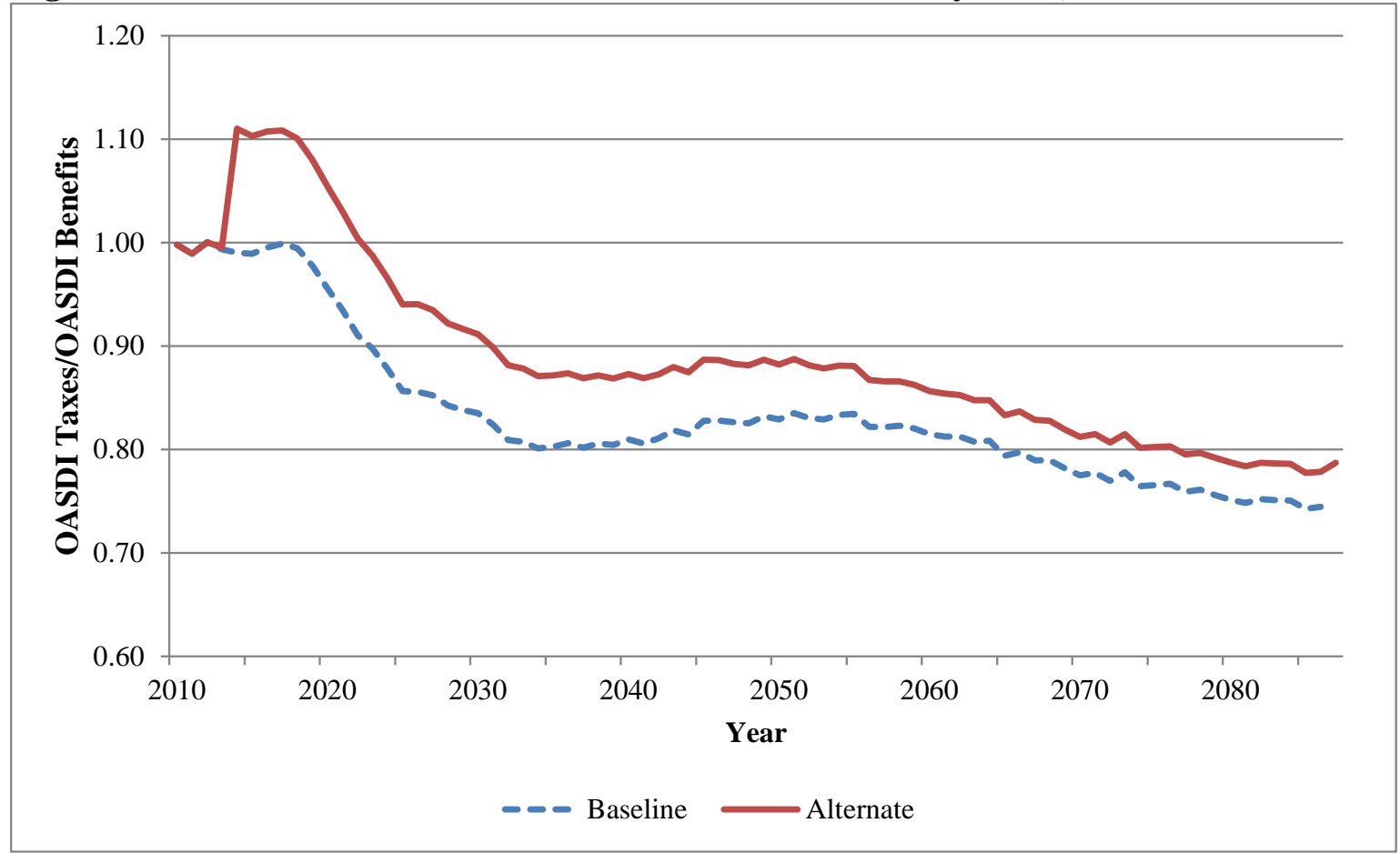

Source: Authors' calculations from DYNASIM3.

Notes: OASDI benefits are net of federal income taxes (tier 1) paid to the OASDI trust fund. 
not eliminate the long-term financing deficit and would close a declining share of the deficit over time.

The contributions taxpayers and beneficiaries make to this improved trust fund balance differ by age. We can calculate each cohort's contribution as the change in the present value of OASDI taxes and benefits from including ESI benefits in earnings. Most older Americans have no change in either OASDI taxes or benefits because they had stopped working and claimed benefits before 2014 (figure 3). But for younger individuals, adding ESI premiums to taxable earnings increases OASDI taxes more than benefits. The gap between taxes and benefits is wider for younger than for older cohorts.

In performing this calculation, we use a 2 percent real discount rate. For years an individual is married, we assign each individual half the couple's total OASDI taxes and Social Security benefits. For years an individual is single, we include only the individual's own OASDI taxes and Social Security benefits.

Figure 3. Change in Present Discounted Value of Shared Lifetime OASDI Taxes and Benefits by Age in 2014.

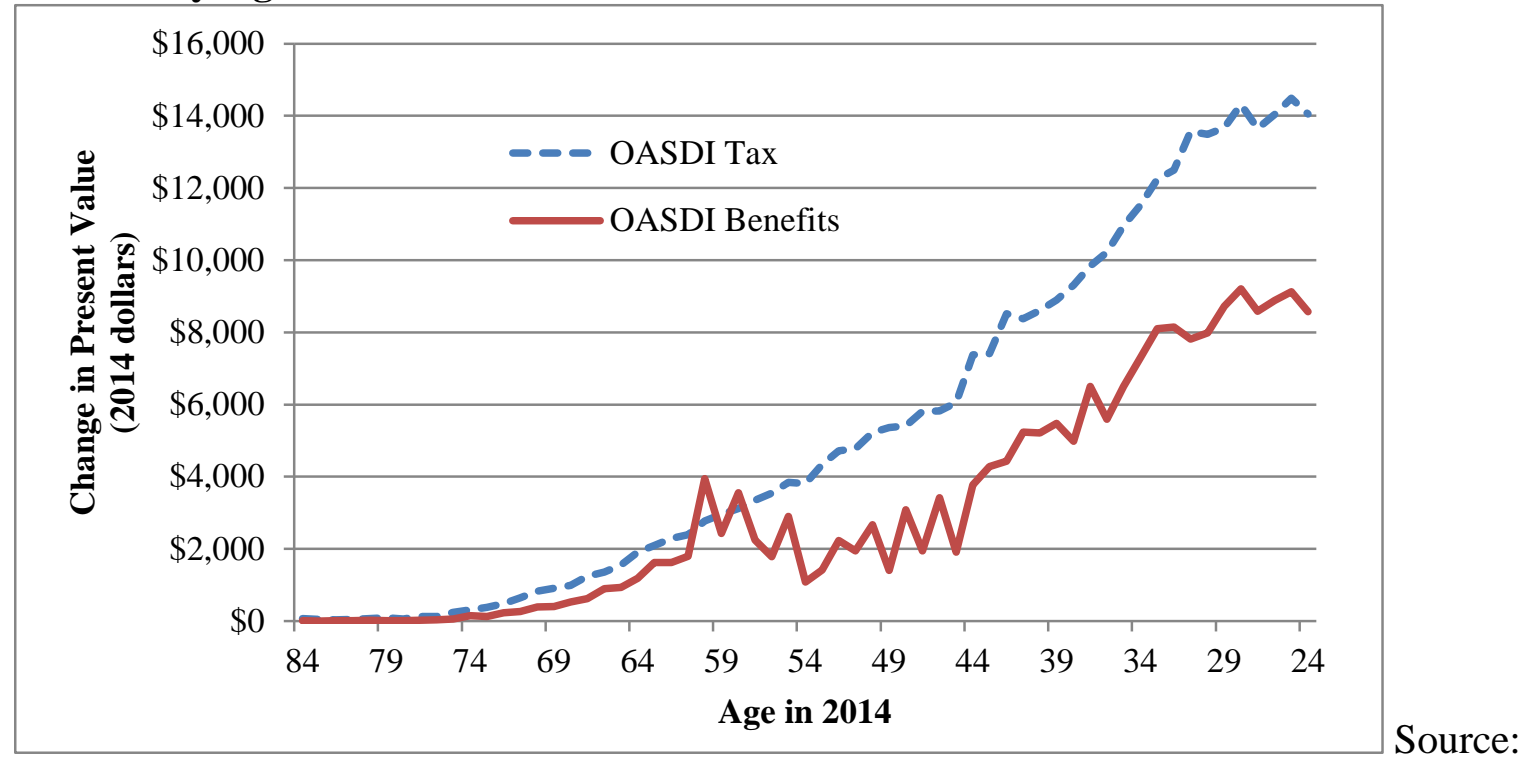

Authors calculations from DYNASIM3. 


\section{Distribution of ESI Premiums}

DYNASIM and TPC project that under current law (including the effects of the ACA) almost 70 percent of tax units with earnings will receive health insurance coverage from their employers in 2014. (See table 5 and figure 4). The percentage of tax units with earnings with coverage rises from less than 20 percent in the bottom income quintile to over 90 percent in the top 5 percent. Coverage rates of tax units with earnings increase with age of tax unit head, rising from slightly under 65 percent for those ages 25 through 34 to about 75 percent for those ages 45 through 64, before dropping to 55 percent for workers ages 65 and over. Average tax-exempt premiums among all tax units rise with income throughout the income distribution, but decline as a share of income for taxpayers in the top half of the distribution, falling from 11.5 percent of income for those in the middle income quintile to 2.6 percent of income for those in the top five percent. ${ }^{11}$ Average premiums among all tax units and among those with premiums are highest at ages 35 through 44, but premiums as a percentage of income are higher for younger than for older workers throughout the age distribution.

\footnotetext{
${ }^{11}$ Tax-exempt premiums include those that employers pay and those that employees pay through a cafeteria plan.
} 
Figure 4. Percent of Tax Units with Earnings and ESI by Income and Age in 2014

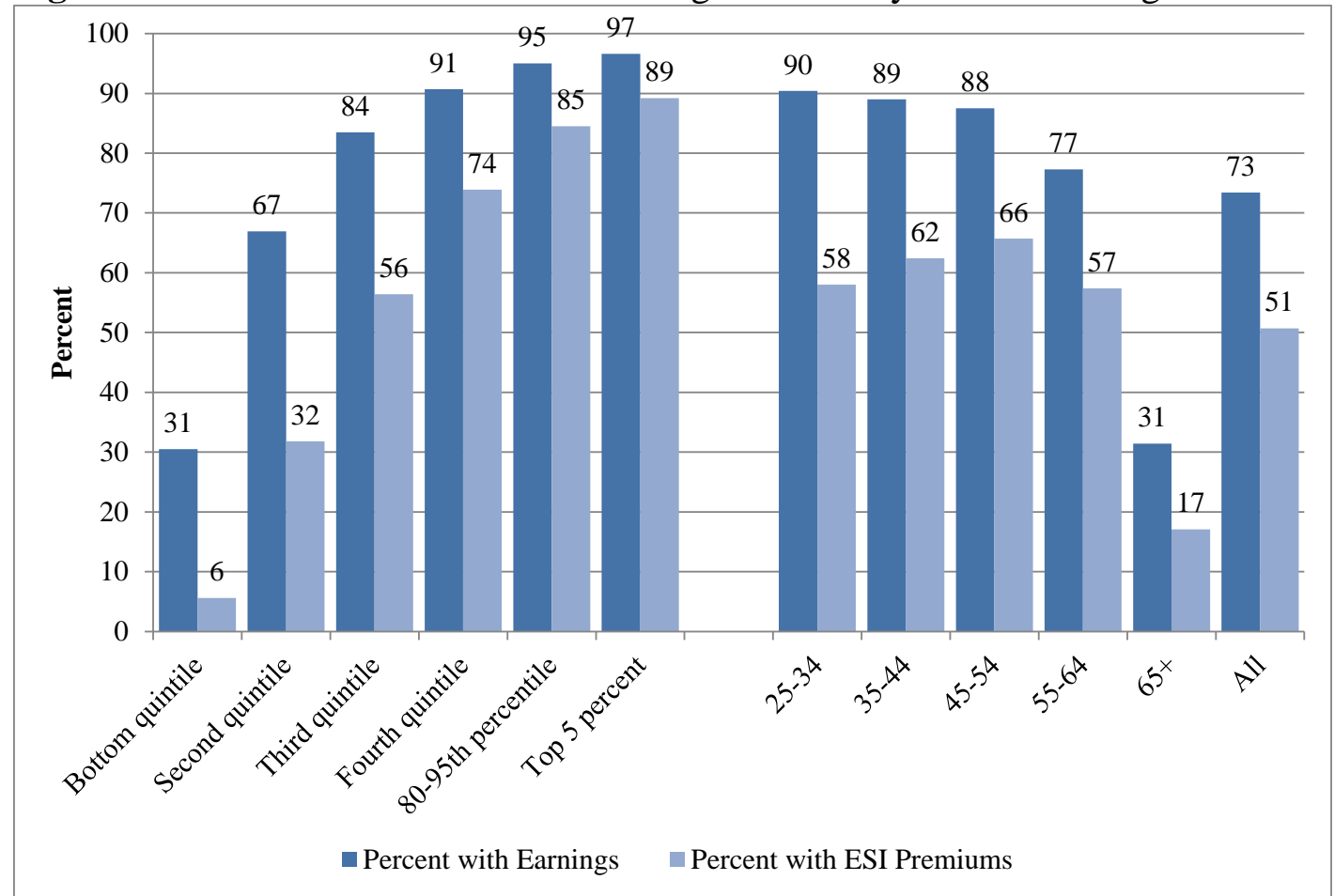

Source: Authors calculations from DYNASIM3. 
Table 5. Distribution of ESI Exclusion by Income Group and Age in 2014

\begin{tabular}{|c|c|c|c|c|c|c|c|c|c|}
\hline & $\begin{array}{c}\text { Number of } \\
\text { units } \\
\text { (thousands) }\end{array}$ & $\begin{array}{c}\text { Average } \\
\text { income } \\
/ 1\end{array}$ & $\begin{array}{c}\text { Average } \\
\text { earnings } \\
\text { /2 }\end{array}$ & $\begin{array}{c}\text { Average } \\
\text { Tax- } \\
\text { Exempt } \\
\text { ESI } \\
\text { premium } \\
\text { /3 }\end{array}$ & $\begin{array}{c}\text { Average } \\
\text { premium } \\
\text { among those } \\
\text { with } \\
\text { premiums }\end{array}$ & $\begin{array}{c}\text { ESI } \\
\text { premiums } \\
\text { as \% of } \\
\text { income }\end{array}$ & $\begin{array}{c}\text { Percent } \\
\text { with } \\
\text { earnings }\end{array}$ & $\begin{array}{l}\text { Percent } \\
\text { with } \\
\text { premiums }\end{array}$ & $\begin{array}{l}\text { Percent of } \\
\text { workers } \\
\text { with } \\
\text { premiums } \\
\text { /4 }\end{array}$ \\
\hline & (a) & (b) & (c) & (d) & (e ) & (f) & (g) & (h) & (i) \\
\hline \multicolumn{10}{|l|}{ Income group } \\
\hline Bottom quintile & 29,760 & 8,962 & 3,574 & 289 & 5,161 & 3.2 & 30.5 & 5.6 & 18.4 \\
\hline Second quintile & 29,763 & 27,828 & 17,346 & 2,445 & 7,689 & 8.8 & 66.9 & 31.8 & 47.5 \\
\hline Third quintile & 29,760 & 52,115 & 39,292 & 5,980 & 10,603 & 11.5 & 83.5 & 56.4 & 67.5 \\
\hline Fourth quintile & 29,760 & 87,769 & 70,822 & 9,272 & 12,547 & 10.6 & 90.7 & 73.9 & 81.5 \\
\hline 80-95th percentile & 22,319 & 152,409 & 126,527 & 11,316 & 13,392 & 7.4 & 95.0 & 84.5 & 88.9 \\
\hline Top 5 percent & 7,439 & 458,960 & 324,757 & 12,109 & 13,575 & 2.6 & 96.6 & 89.2 & 92.3 \\
\hline \multicolumn{10}{|l|}{ Age } \\
\hline $25-34$ & 30,158 & 66,924 & 62,982 & 7,468 & 12,876 & 11.2 & 90.4 & 58.0 & 64.2 \\
\hline $35-44$ & 27,606 & 96,743 & 87,631 & 8,225 & 13,181 & 8.5 & 89.0 & 62.4 & 70.1 \\
\hline $45-54$ & 29,395 & 97,165 & 86,393 & 6,820 & 10,381 & 7.0 & 87.5 & 65.7 & 75.1 \\
\hline $55-64$ & 26,845 & 86,079 & 64,134 & 5,962 & 10,387 & 6.9 & 77.3 & 57.4 & 74.3 \\
\hline $65+$ & 34,798 & 63,733 & 16,083 & 1,872 & 10,947 & 2.9 & 31.4 & 17.1 & 54.5 \\
\hline All & 148,802 & 81,139 & 61,420 & 5,900 & 11,637 & 7.3 & 73.4 & 50.7 & 69.1 \\
\hline
\end{tabular}

Source: Authors' calculations from DYNASIM3.

1/ Includes wage compensation, employer share of payroll tax, employer DC contributions, exempt ESI benefits, Social Security, DB pension, interest, dividends, rental income, capital gains, SSI, return on DC assets, withdrawals from retirement accounts.

2/ Includes wage compensation, employer share of payroll tax, employer DC contributions, and both employer premiums and employee premiums that are tax-exempt under cafeteria plans.

3/ Both employer premiums and employee premiums that are tax-exempt under cafeteria plans.

4/ Workers are defined as tax units with earned income. 


\section{Distribution of Taxes and Present Value of OASDI Benefits}

Including ESI in the base for income and payroll taxes increases tax liability for workers who receive ESI benefits (table 6 and figure 5). The distribution of the increase in the average tax rate by income and age groups has roughly the same pattern as the distribution of ESI premiums by income and age group. The tax increase as a percentage of income (column h) rises from 0.5 percent in the bottom quintile to 3.4 percent in the middle quintile, but then declines to 2.3 percent for the $80-95^{\text {th }}$ percentiles and 0.9 percent for the top 5 percent. ${ }^{12}$ Among age groups, the increase in the average tax rate declines from 3.3 percent of income for tax units ages 25-34 to 2.0 percent for tax units ages 45-64 and then drops further to 0.9 percent for tax units ages 65 and over. There are differences among income groups, however, in the relative effects of income and payroll taxes. Because of the graduated income tax rate structure and the cap on the OASDI tax at wages of $\$ 117,900$, lower income households are hit relatively harder by the payroll tax increase and higher income households by the income tax increase. ${ }^{13}$ The payroll tax increase is larger than the income tax increase in the bottom two quintiles of the distribution, but is less than a fourth of the income tax increase for the top 5 percent. Overall, the payroll tax increase is about 65 percent of the income tax increase. OASDI taxes account for slightly under four-fifths of the increased payroll tax receipts.

\footnotetext{
${ }^{12}$ CBO (2013) shows a slightly different distribution pattern, with tax burdens higher in the bottom two quintiles than in the middle quintile. We suspect the reason for the difference is that CBO ranks units by income divided by the poverty threshold for its family size, which makes families with children look relatively poorer than a measure based on total income alone. So CBO has relatively more units in the bottom quintile who receive a family ESI benefit than an individual benefit, compared with DYNASIM.

${ }^{13}$ The $\$ 117,900$ wage cap is the 2014 projected value based on Social Security Trustees 2012 intermediate cost assumptions.
} 
Table 6. Distribution of Tax Changes from eliminating ESI Exclusion by Income Group and Age in 2014

\begin{tabular}{|c|c|c|c|c|c|c|c|c|}
\hline & $\begin{array}{c}\text { Percent } \\
\text { with } \\
\text { payroll tax } \\
\text { increase }\end{array}$ & $\begin{array}{c}\text { Average } \\
\text { OASDI tax } \\
\text { change }\end{array}$ & $\begin{array}{l}\text { Average HI } \\
\text { tax change }\end{array}$ & $\begin{array}{c}\text { Average } \\
\text { payroll tax } \\
\text { change }\end{array}$ & $\begin{array}{l}\text { Average } \\
\text { income tax } \\
\text { change }\end{array}$ & $\begin{array}{c}\text { Average } \\
\text { Medicare } \\
\text { surtax } \\
\text { change }\end{array}$ & $\begin{array}{l}\text { Average } \\
\text { total tax } \\
\text { change }^{/ 1}\end{array}$ & $\begin{array}{c}\text { Tax change } \\
\text { as \% of } \\
\text { income }\end{array}$ \\
\hline & (a) & (b) & (c) & (d) & (e ) & (f) & (g) & (h) \\
\hline \multicolumn{9}{|l|}{ Income group } \\
\hline Bottom quintile & 5.2 & 30 & 7 & 36 & 12 & 0 & 48 & 0.5 \\
\hline Second quintile & 29.3 & 249 & 58 & 307 & 226 & 0 & 533 & 1.9 \\
\hline Third quintile & 51.5 & 615 & 144 & 759 & 1021 & 0 & 1780 & 3.4 \\
\hline $\begin{array}{l}\text { Fourth quintile } \\
\text { 80-95th }\end{array}$ & 68.6 & 973 & 227 & 1201 & 1398 & 0 & 2599 & 2.9 \\
\hline percentile & 79.1 & 963 & 280 & 1243 & 2356 & 0 & 3599 & 2.3 \\
\hline Top 5 percent & 83.5 & 509 & 309 & 818 & 3336 & 56 & 4210 & 0.9 \\
\hline \multicolumn{9}{|l|}{ Age } \\
\hline 25-34 & 55.1 & 736 & 190 & 925 & 1289 & 2 & 2216 & 3.3 \\
\hline $35-44$ & 56.6 & 723 & 198 & 921 & 1504 & 4 & 2429 & 2.5 \\
\hline $45-54$ & 61.0 & 601 & 166 & 767 & 1235 & 3 & 2005 & 2.0 \\
\hline $55-64$ & 53.5 & 552 & 147 & 698 & 1021 & 3 & 1722 & 2.0 \\
\hline $65^{+}$ & 15.3 & 179 & 44 & 223 & 356 & 2 & 581 & 0.9 \\
\hline All & 47.0 & 543 & 145 & 688 & 1052 & 3 & 1743 & 2.1 \\
\hline
\end{tabular}

Source: Authors' calculations from DYNASIM3.

Notes: Payroll tax is the sum of worker and employer OASI, DI, HI tax. Details may not add to totals due to rounding.

${ }^{1 /}$ Total tax is the sum of payroll tax, federal income tax, and Medicare surtax. 
Figure 5. Tax Change as a Percent of Income by Income Group and Age in 2014

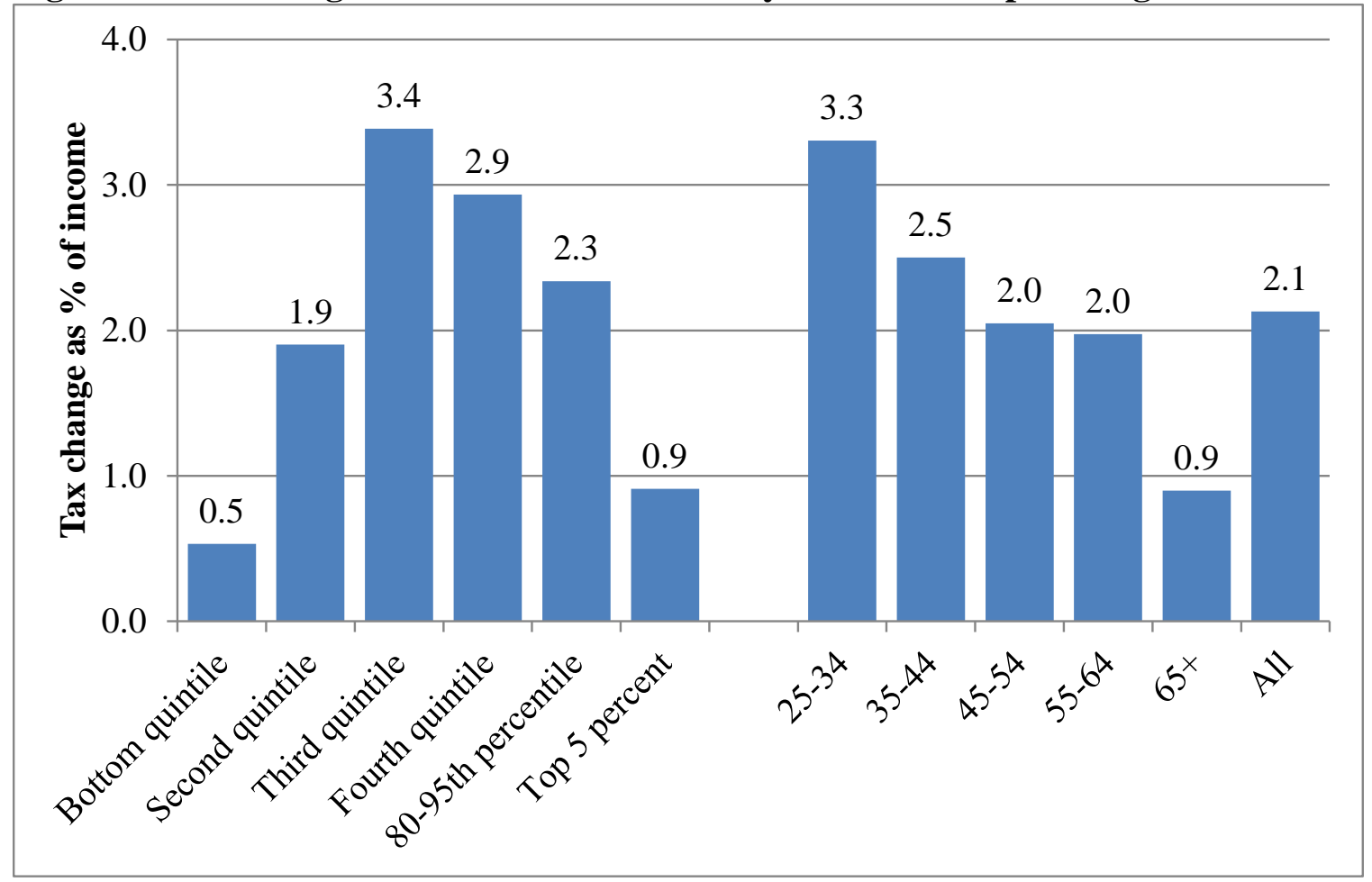

Source: Author's tabulations from DYNASIM3.

The one-year inclusion of ESI in the earnings base in 2014 raises the present value of Social Security retirement and disability benefits by an average of about $\$ 391$ per tax unit, or 0.5 percent of income (table 7, column f, and figure 6). . As a share of income, the present value of additional benefits (Table 7, column g) rises from 0.5 percent for units in the bottom quintile to 0.9 percent for units in the middle quintile, before dropping to 0.4 percent in the $80-95^{\text {th }}$ percentiles and 0.1 percent for the top 5 percent. Additional benefits as a share of income are 0.7 percent for households with a younger head (ages 25-34), about 0.5 percent for households with a head between ages 35 and 64, and 0.2 percent for households with a head age 65 or older. 
Table 7. Distribution of Changes in Present Value of Social Security Benefits from eliminating ESI Exclusion by Income Group and Age in 2014

\begin{tabular}{|c|c|c|c|c|c|c|c|c|c|}
\hline & $\begin{array}{l}\text { Present } \\
\text { value of } \\
\text { baseline } \\
\text { Social } \\
\text { Security } \\
\text { benefits }\end{array}$ & $\begin{array}{l}\text { Present value } \\
\text { of baseline } \\
\text { Social } \\
\text { Security } \\
\text { benefits with } \\
\text { adjusted AWI }\end{array}$ & $\begin{array}{l}\text { Present } \\
\text { value of } \\
\text { alternate } \\
\text { Social } \\
\text { Security } \\
\text { benefits }\end{array}$ & $\begin{array}{c}\text { Percent } \\
\text { with } \\
\text { benefit } \\
\text { increase }\end{array}$ & $\begin{array}{l}\text { Benefits } \\
\text { from } \\
\text { wage } \\
\text { indexing }\end{array}$ & $\begin{array}{l}\text { Benefits } \\
\text { from } \\
\text { including } \\
\text { ESI in } \\
\text { wage base }\end{array}$ & $\begin{array}{c}\text { Benefit } \\
\text { change } \\
\text { as a } \\
\text { percent } \\
\text { of } \\
\text { income }\end{array}$ & $\begin{array}{c}\text { Tax } \\
\text { change } \\
\text { as a } \\
\text { percent } \\
\text { of } \\
\text { income }\end{array}$ & $\begin{array}{l}\text { Net tax } \\
\text { change } \\
\text { as a } \\
\text { percent } \\
\text { of } \\
\text { income }\end{array}$ \\
\hline & (a) & (b) & (c) & (d) & (e ) & (f) & (g) & (h) & (i) \\
\hline \multicolumn{10}{|l|}{ Income group } \\
\hline Bottom quintile & 141,946 & 141,520 & 141,569 & 10 & $(426)$ & 49 & $0.5 \%$ & $0.5 \%$ & $0.0 \%$ \\
\hline Second quintile & 211,985 & 211,357 & 211,556 & 27 & (628) & 199 & $0.7 \%$ & $1.9 \%$ & $1.2 \%$ \\
\hline Third quintile & 280,879 & 279,798 & 280,263 & 47 & $(1,081)$ & 465 & $0.9 \%$ & $3.4 \%$ & $2.5 \%$ \\
\hline Fourth quintile & 376,482 & 374,887 & 375,583 & 64 & $(1,595)$ & 696 & $0.8 \%$ & $2.9 \%$ & $2.1 \%$ \\
\hline $80-95^{\text {th }}$ percentile & 488,405 & 486,148 & 486,778 & 62 & $(2,257)$ & 630 & $0.4 \%$ & $2.3 \%$ & $1.9 \%$ \\
\hline Top 5 percent & 582,368 & 579,556 & 579,857 & 38 & $(2,812)$ & 301 & $0.1 \%$ & $0.9 \%$ & $0.8 \%$ \\
\hline \multicolumn{10}{|l|}{ Age } \\
\hline $25-34$ & 270,255 & 268,373 & 268,867 & 50 & $(1,882)$ & 494 & $0.7 \%$ & $3.3 \%$ & $2.6 \%$ \\
\hline $35-44$ & 303,954 & 301,830 & 302,344 & 49 & $(2,124)$ & 514 & $0.5 \%$ & $2.5 \%$ & $2.0 \%$ \\
\hline $45-54$ & 342,414 & 339,876 & 340,303 & 52 & $(2,538)$ & 427 & $0.4 \%$ & $2.0 \%$ & $1.6 \%$ \\
\hline $55-64$ & 374,660 & 374,969 & 375,408 & 45 & 309 & 439 & $0.5 \%$ & $2.0 \%$ & $1.5 \%$ \\
\hline $65+$ & 249,023 & 249,006 & 249,144 & 13 & $(17)$ & 138 & $0.2 \%$ & $0.9 \%$ & $0.7 \%$ \\
\hline All & 304,632 & 303,407 & 303,798 & 41 & (1225) & 391 & $0.5 \%$ & $2.1 \%$ & $1.7 \%$ \\
\hline
\end{tabular}

Source: Authors' calculations from DYNASIM3.

Notes: Individuals who are currently single will receive half of any incremental benefit of themselves and their spouse in future years when they are getting benefits and are married. Couples who are currently married receive the sum of each spouse's future incremental benefits. Details may not add to totals due to rounding. 
Figure 6. Tax and Benefit Change as a Percent of Income by Income Group and Age in 2014

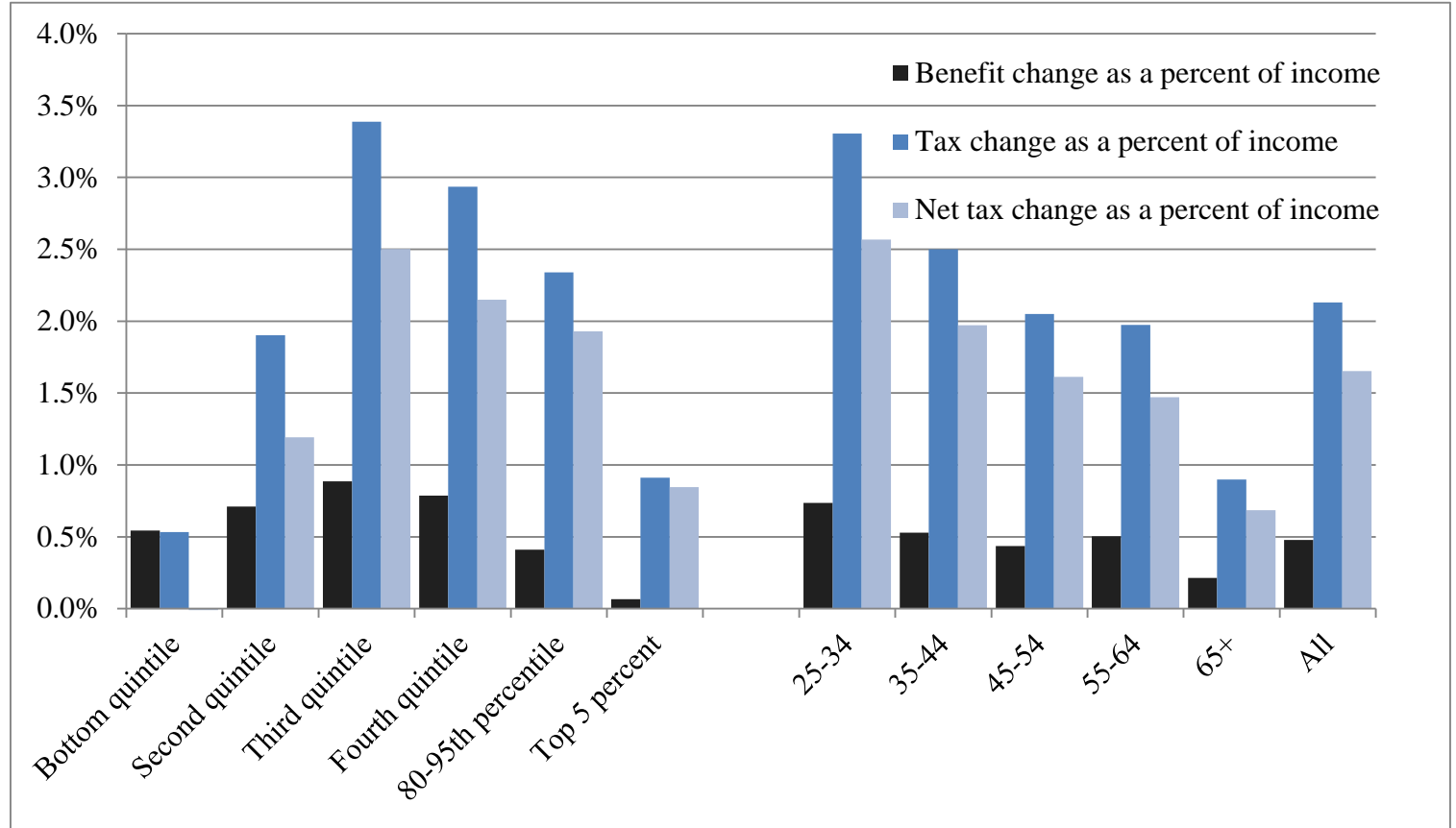

Source: Authors’ calculations from DYNASIM3.

About 40 percent of tax units receive additional benefits, compared with 47 percent who pay higher payroll taxes (table 8, columns a and d). In comparison, 49.1 percent experience an increase in income taxes (column e). Individuals can experience an increase in payroll taxes, but receive no increase in the present value of Social Security benefits, if their earnings are above the OASDI wage cap, if their future benefits are based on a future or past spouse's earnings instead of their own, or if they work in an uncovered job. But some individuals may also receive higher (shared) future benefits without paying more payroll taxes if a future spouse experiences an increase in her future benefits due to higher current taxable earnings. Therefore the percent with a change in either tax or benefits (column i) is higher than both the percent with a change in benefits (column a) and the percent with a change in payroll taxes (column d) for all income and age groups. 
Table 8. Percent with Increased Benefits or Taxes from Including ESI Premiums in Income Group and Age in 2014

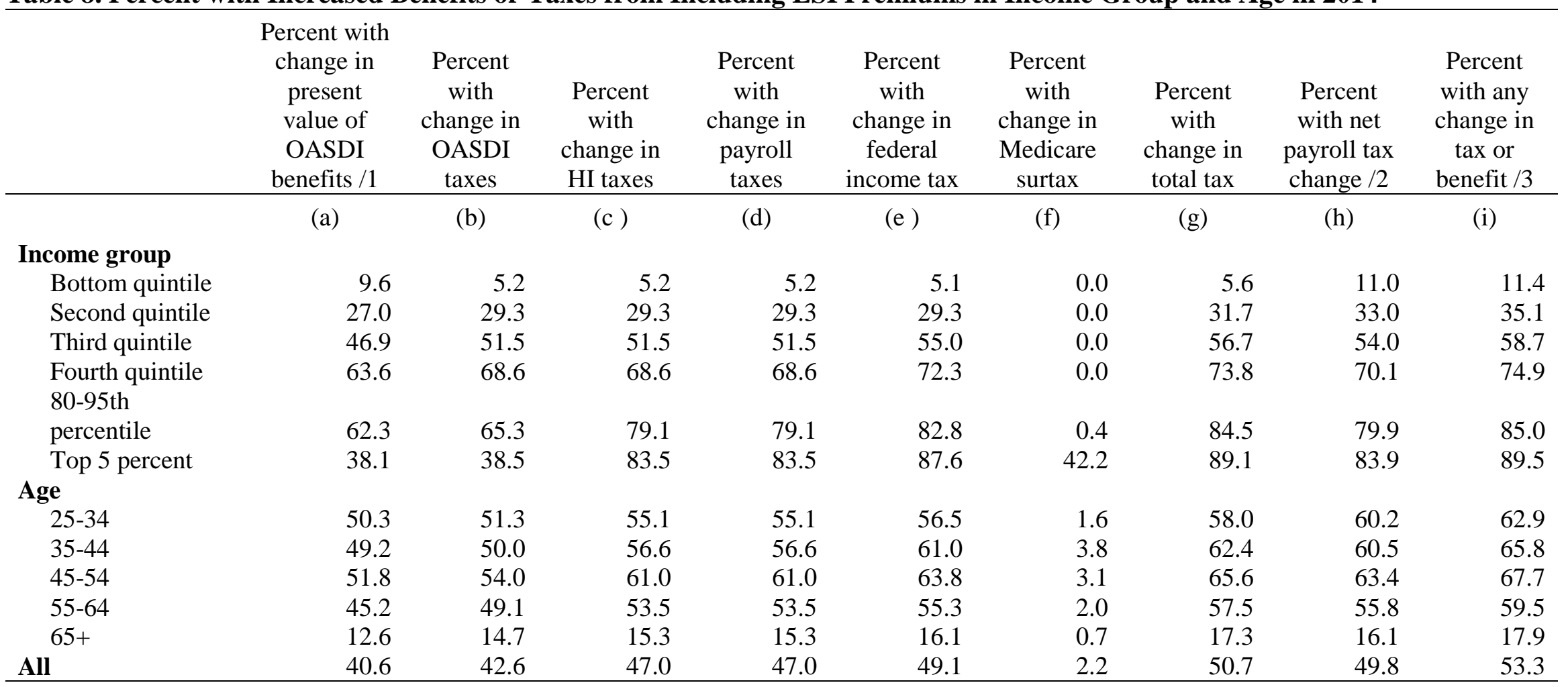

Source: Authors' calculations from DYNASIM3.

Notes: Individuals who are currently single will receive half of any incremental benefit of themselves and their spouse in future years when they are getting benefits and are married. Couples who are currently married receive the sum of each spouse's future incremental benefits.

1/ Percent with a change in the present value of OASDI from including ESI in the wage base minus the present value of OASDI excluding ESI using updated AWI.

2/ Percent with change in payroll tax not equal to the change in present value of OASDI benefits with 2014 taxable ESI.

3/ Percent with change in total tax (federal, payroll, surtax) not equal to the change in present value of OASDI benefits with 2014 taxable ESI. 
Overall, the present value of additional benefits equals 22 percent of the increase in both income and payroll taxes, 57 percent of the increase in payroll taxes, and 72 percent of the increase in OASDI taxes (table 9, columns i-k). But the ratio of increased benefits to taxes varies substantially among income groups.

Table 9. Summary: Comparison of Taxes and Benefits by Income and Age in 2014

\begin{tabular}{lrrr} 
& Ratio of OASDI & $\begin{array}{c}\text { Ratio of OASDI } \\
\text { Benefits to Payroll } \\
\text { Tax }^{\prime 2}\end{array}$ & $\begin{array}{c}\text { Ratio of OASDI } \\
\text { Benefits to OASDI } \\
\text { Tax }\end{array}$ \\
\hline Income group & & & \\
$\quad$ Bottom quintile & $102.1 \%$ & $136.1 \%$ & $163.3 \%$ \\
$\quad$ Second quintile & $37.3 \%$ & $64.8 \%$ & $79.9 \%$ \\
$\quad$ Third quintile & $26.1 \%$ & $61.3 \%$ & $71.5 \%$ \\
$\quad$ Fourth quintile & $26.8 \%$ & $58.0 \%$ & $65.4 \%$ \\
80-95th percentile & $17.5 \%$ & $50.7 \%$ & $59.1 \%$ \\
$\quad$ Top 5 percent & $7.1 \%$ & $36.8 \%$ & \\
Age & & & $71.1 \%$ \\
25-34 & $22.3 \%$ & $53.4 \%$ & $71.0 \%$ \\
35-44 & $21.2 \%$ & $55.8 \%$ & $79.5 \%$ \\
45-54 & $21.3 \%$ & $55.7 \%$ & $77.1 \%$ \\
55-64 & $25.5 \%$ & $62.9 \%$ & $72.0 \%$ \\
65+ & $23.8 \%$ & $61.9 \%$ & \\
All & $22.4 \%$ & $56.8 \%$ & \\
\hline
\end{tabular}

Source: Authors' calculations from DYNASIM3.

1/ Ratio of benefits (from table 7 column f) to taxes (from table 6 column g).

2/ Ratio of benefits (from table 7 column f) to payroll taxes (from table 6 column d).

3/ Ratio of benefits (from table 7 column $\mathrm{f}$ ) to OASDI taxes (from table 6 column b).

The bottom quintile recovers in higher benefits slightly over 100 percent of their increased taxes, 136 percent of their increased payroll taxes, and over 163 percent of their increased OASDI taxes. So broadening the payroll tax to include ESI on balance helps tax units in the bottom quintile of the income distribution. The ratio of increased benefits to higher payroll taxes is less than one for all other income groups, dropping to 51 percent for tax units in the 80$95^{\text {th }}$ percentiles of the income distribution and to only 37 percent for tax units in the top 5 percent. 


\section{Distributional Effects by Lifetime Earnings and Cohort}

Another way of looking at distributional analysis is to examine how introduction of a policy change in a given year affects people in different birth cohorts, who experience the phasing in of changes in their retirement benefits. For example, if ESI were included in the taxable wage base beginning in 2014, workers near retirement would only receive future benefits based on increased covered earnings in a few years, while younger workers would receive benefits based on increased covered earnings through most of their lifetime.

For the lifetime simulations, we group individuals by their rank within their birth cohort of the present value of shared lifetime earnings, where in any year shared earnings is the individual's earnings if single and half the couple's earnings if married.

In contrast to the snapshot simulations (column $\mathrm{f}$ of Table 5), the ratio of the present value of lifetime ESI premiums to the present value of earnings declines throughout the earnings distribution between the bottom quintile and the top 5 percent (table 10). For individuals born between 1950 and 1959, the present value of ESI premiums is 14.4 percent of the present value of lifetime earnings in the bottom quintile of the earnings distribution and 4.7 percent of lifetime earnings in the top quintile. For individuals born between 1990 and 1999, the present value of ESI premiums is 15.6 percent of the present value of lifetime earnings in the bottom quintile of the earnings distribution and 3.1 percent of lifetime earnings in the top quintile. The decline in the ratio of lifetime ESI premiums to lifetime earnings between the 1950-59 and 1960-69 premiums reflects a rise in lifetime earnings (relative to benefits) between the 1950-59 and 196069 cohorts due to higher female labor participation rates and higher labor force participation for both males and females at older ages. The especially large proportional drop in the ratio for the top 5 percent between 1950-59 and 1970-79 (from 4.7 percent to 2.2 percent) reflects the increased inequality of earnings at the top of income distribution, which is much greater proportionately than the increase in ESI benefits received. 
Table 10. Ratio of Present Value of ESI Premiums to Present Value of Lifetime Earnings by Lifetime Earnings Groups and Birth Cohort

\begin{tabular}{lccccc}
\hline & \multicolumn{5}{c}{ Birth Cohort } \\
Lifetime earnings group / 1 & $1950-59$ & $1960-69$ & $1970-79$ & $1980-89$ & $1990-99$ \\
\cline { 2 - 6 } & & & & & \\
Bottom quintile & 0.144 & 0.127 & 0.143 & 0.159 & 0.156 \\
Second quintile & 0.134 & 0.119 & 0.140 & 0.155 & 0.147 \\
Third quintile & 0.124 & 0.105 & 0.124 & 0.134 & 0.126 \\
Fourth quintile & 0.105 & 0.085 & 0.102 & 0.109 & 0.104 \\
80-95th percentile & 0.084 & 0.062 & 0.070 & 0.080 & 0.076 \\
Top 5 percent & 0.047 & 0.029 & 0.022 & 0.033 & 0.031 \\
Total & 0.091 & 0.073 & 0.080 & 0.096 & 0.092 \\
\hline
\end{tabular}

Source: Authors' calculations from DYNASIM3.

1 / Lifetime earnings group includes both employer and employee premiums that are taxexempt under cafeteria plans. Assumes proposal is effective on 1/1/2014. People are ranked by shared lifetime earnings within their birth cohort.

The ratios of the increased lifetime OASDI taxes and total (OASDI and HI) payroll taxes to lifetime earnings illustrates that the increase in payroll taxes remains regressive throughout the lifetime earnings distribution for all five cohort groups (tables 11 and 12), reflecting the declining ratio of ESI to earnings as earnings rise (table 10) and the OASDI wage cap for high earners. For example, for the 1990-99 birth cohorts, the present value of the payroll tax increase is 1.9 percent of lifetime earnings for the bottom quintile of earners, but only 0.2 percent of lifetime earnings for the top 5 percent. In contrast, the ratio of the present value of the entire tax increase (including the income tax portion) to the present value of earnings increases slightly between the first and second quintiles of the distribution for all cohorts, before declining at the top (table 13). 
Table 11. Ratio of Present Value of OASDI Tax Increase to Present Value of Lifetime Earnings by Lifetime Earnings Group and Birth Cohort

\begin{tabular}{lccccc}
\hline & \multicolumn{5}{c}{ Birth Cohort } \\
& $1950-59$ & $1960-69$ & $1970-79$ & $1980-89$ & $1990-99$ \\
\cline { 2 - 6 } Lifetime earnings group / & & & & & \\
Bottom quintile & 0.016 & 0.013 & 0.014 & 0.016 & 0.015 \\
Second quintile & 0.014 & 0.012 & 0.014 & 0.016 & 0.015 \\
Third quintile & 0.013 & 0.011 & 0.012 & 0.013 & 0.013 \\
Fourth quintile & 0.011 & 0.008 & 0.010 & 0.011 & 0.010 \\
80-95th percentile & 0.008 & 0.005 & 0.006 & 0.007 & 0.007 \\
Top 5 percent & 0.004 & 0.002 & 0.001 & 0.002 & 0.002 \\
Total & 0.009 & 0.007 & 0.007 & 0.009 & 0.009 \\
\hline
\end{tabular}

Source: Authors' calculations from DYNASIM3.

1/ Lifetime earnings group includes both employer and employee premiums that are taxexempt under cafeteria plans. Assumes proposal is effective on 1/1/2014. People are ranked by shared lifetime earnings within their birth cohort.

2/ OASDI tax includes both employer and employee share.

Table 12. Ratio of Present Value of Payroll Tax Increase to Present Value of Lifetime Earnings by Lifetime Earnings Group and Birth Cohort /2

\begin{tabular}{lccccc}
\hline & \multicolumn{5}{c}{ Birth Cohort } \\
& $1950-59$ & $1960-69$ & $1970-79$ & $1980-89$ & $1990-99$ \\
\cline { 2 - 6 } Lifetime earnings group / & & & & & \\
Bottom quintile & 0.019 & 0.016 & 0.017 & 0.020 & 0.019 \\
Second quintile & 0.017 & 0.015 & 0.017 & 0.019 & 0.018 \\
Third quintile & 0.016 & 0.013 & 0.015 & 0.017 & 0.016 \\
Fourth quintile & 0.013 & 0.010 & 0.012 & 0.013 & 0.013 \\
80-95th percentile & 0.010 & 0.007 & 0.008 & 0.009 & 0.009 \\
Top 5 percent & 0.005 & 0.003 & 0.002 & 0.003 & 0.002 \\
Total & 0.011 & 0.009 & 0.009 & 0.011 & 0.011 \\
\hline
\end{tabular}

Source: Authors' calculations from DYNASIM3.

1/ Lifetime earnings group includes both employer and employee premiums that are taxexempt under cafeteria plans. Assumes proposal is effective on 1/1/2014. People are ranked by shared lifetime earnings within their birth cohort.

2/ Payroll tax includes both employer and employee share of OASDI and HI tax. 
Table 13. Ratio of Present Value of Total Tax (OASDI + HI + Surtax + Federal) Increase to Present Value of Lifetime Earnings by Lifetime Earnings Group and Birth Cohort

\begin{tabular}{lccccc}
\hline & \multicolumn{5}{c}{ Birth Cohort } \\
& $1950-59$ & $1960-69$ & $1970-79$ & $1980-89$ & $1990-99$ \\
\cline { 2 - 6 } Lifetime earnings group /1 & & & & & \\
Bottom quintile & 0.031 & 0.026 & 0.030 & 0.033 & 0.033 \\
Second quintile & 0.033 & 0.029 & 0.034 & 0.038 & 0.037 \\
Third quintile & 0.035 & 0.029 & 0.034 & 0.037 & 0.035 \\
Fourth quintile & 0.033 & 0.026 & 0.031 & 0.034 & 0.032 \\
80-95th percentile & 0.028 & 0.021 & 0.023 & 0.027 & 0.026 \\
Top 5 percent & 0.017 & 0.010 & 0.008 & 0.011 & 0.011 \\
Total & 0.028 & 0.022 & 0.023 & 0.028 & 0.027 \\
\hline
\end{tabular}

Source: Authors' calculations from DYNASIM3.

1 / Lifetime earnings group includes both employer and employee premiums that are taxexempt under cafeteria plans. Assumes proposal is effective on 1/1/2014. People are ranked by shared lifetime earnings within their birth cohort.

2/ OASDI and HI tax include both employer and employee share.

The ratio of the present value of additional Social Security benefits to lifetime earnings follows a similar, but much more pronounced pattern, with the ratio of additional benefits to lifetime earnings declining sharply for higher earnings group (table 14). For example for the 1990-99 birth cohorts, the present value of additional benefits from including ESI in the payroll tax base is 2.1 percent of lifetime earnings for the bottom lifetime earnings group, but only 0.2 percent for the $80-95^{\text {th }}$ percentiles and rounds to zero for the top 5 percent. The highest earners get no benefit from the increased wage base in the years their earnings excluding ESI are above the OASDI threshold, but pay additional income taxes and HI payroll taxes and a larger Medicare surcharge. The 1950-59 birth cohorts fare better on average than later cohorts because the normal retirement age remains at 66 for those born between 1950 and 1954, before beginning to phase up from 66 to 67 for those born between 1955 and 1959. 
Table 14. Ratio of Present Value of Increased Social Security Benefits to Present Value of Lifetime Earnings by Lifetime Earnings Group and Birth Cohort

\begin{tabular}{lccccc}
\hline & \multicolumn{5}{c}{ Birth Cohort } \\
& $1950-59$ & $1960-69$ & $1970-79$ & $1980-89$ & $1990-99$ \\
\cline { 2 - 6 } Lifetime earnings group / & & & & & \\
Bottom quintile & 0.024 & 0.010 & 0.013 & 0.018 & 0.021 \\
Second quintile & 0.013 & 0.007 & 0.010 & 0.014 & 0.013 \\
Third quintile & 0.012 & 0.006 & 0.009 & 0.010 & 0.009 \\
Fourth quintile & 0.009 & 0.003 & 0.005 & 0.006 & 0.005 \\
80-95th percentile & 0.006 & 0.001 & 0.002 & 0.002 & 0.002 \\
Top 5 percent & 0.002 & 0.000 & 0.000 & 0.000 & 0.000 \\
Total & 0.007 & 0.003 & 0.004 & 0.006 & 0.005 \\
\hline
\end{tabular}

Source: Authors' calculations from DYNASIM3.

1/ Lifetime earnings group includes both employer and employee premiums that are taxexempt under cafeteria plans. Assumes proposal is effective on 1/1/2014. People are ranked by shared lifetime earnings within their birth cohort.

Net tax increases are equal to the increased present value of taxes minus the increased present value of benefits. Unlike in the snapshot case, net tax increases on average are positive for all earnings groups (table 15). But the ratio of net taxes to earnings rise throughout most of the earnings distribution even though the taxes themselves are generally regressive, reflecting the very high ratio of benefits to earnings for the lowest earnings groups. Depending on the cohort, the ratio of net taxes to earnings peaks for either the third of fourth quintile of the distribution before declining very sharply among the highest earners.

The present value of lifetime increased benefits varies among cohorts from 25 percent of lifetime increased taxes for the 1950-59 cohorts to 13 percent for the 1960-69 cohorts, with the ratio stabilizing at about 20 percent for those born in 1980 or later (table 16). In comparison, in the snapshot (Table 9) the present value of increased benefits from including ESI in earnings in 2014 is estimated to be about 22 percent of the increase in income and payroll taxes.) Lower earnings groups recover a much higher share of their increased taxes in the form of higher Social Security benefits than higher income groups. 
Table 15. Summary: Ratio of Present Value of Net Tax Increases from Including ESI in Income to Present Value of Lifetime Earnings by Lifetime Earnings Group and Birth Cohort (percent)

\begin{tabular}{lccccc} 
& \multicolumn{5}{c}{ Birth Cohort } \\
& $1950-59$ & $1960-69$ & $1970-79$ & $1980-89$ & $1990-99$ \\
\cline { 2 - 6 } Lifetime earnings group /1 & & & & & \\
Bottom quintile & $0.6 \%$ & $1.7 \%$ & $1.6 \%$ & $1.5 \%$ & $1.3 \%$ \\
Second quintile & $2.0 \%$ & $2.2 \%$ & $2.3 \%$ & $2.4 \%$ & $2.3 \%$ \\
Third quintile & $2.3 \%$ & $2.4 \%$ & $2.5 \%$ & $2.7 \%$ & $2.6 \%$ \\
Fourth quintile & $2.4 \%$ & $2.3 \%$ & $2.6 \%$ & $2.8 \%$ & $2.7 \%$ \\
80-95th percentile & $2.3 \%$ & $2.0 \%$ & $2.1 \%$ & $2.4 \%$ & $2.3 \%$ \\
Top 5 percent & $1.5 \%$ & $1.0 \%$ & $0.8 \%$ & $1.1 \%$ & $1.1 \%$ \\
Total & $2.1 \%$ & $1.9 \%$ & $1.9 \%$ & $2.3 \%$ & $2.2 \%$ \\
\hline Souryyyy
\end{tabular}

Source: Authors' calculations from DYNASIM3.

1/ Lifetime earnings group includes both employer and employee premiums that are tax-exempt under cafeteria plans. Assumes proposal is effective on 1/1/2014. People are ranked by shared lifetime earnings within their birth cohort.

2/ Net tax increase is the change in present value of total tax (OASDI+HI+Federal+Surtax) minus the change in present value of OASDI benefits.

Table 16. Ratio of Present Value of Benefits to Total Tax Increases by Lifetime Earnings Group (percent)

\begin{tabular}{lccccc}
\hline & \multicolumn{5}{c}{ Birth Cohort } \\
& $1950-59$ & $1960-69$ & $1970-79$ & $1980-89$ & $1990-99$ \\
\cline { 2 - 6 } Lifetime earnings group /1 & & & & \\
Bottom quintile & $79.3 \%$ & $36.7 \%$ & $44.4 \%$ & $54.4 \%$ & $61.9 \%$ \\
Second quintile & $38.7 \%$ & $24.9 \%$ & $31.1 \%$ & $36.3 \%$ & $36.0 \%$ \\
Third quintile & $34.4 \%$ & $20.0 \%$ & $25.6 \%$ & $26.5 \%$ & $26.3 \%$ \\
Fourth quintile & $27.2 \%$ & $12.6 \%$ & $17.5 \%$ & $17.0 \%$ & $16.4 \%$ \\
80-95th percentile & $19.6 \%$ & $5.2 \%$ & $8.3 \%$ & $8.6 \%$ & $8.1 \%$ \\
Top 5 percent & $10.5 \%$ & $-2.0 \%$ & $-0.9 \%$ & $0.9 \%$ & $0.7 \%$ \\
Total & $25.4 \%$ & $12.8 \%$ & $17.9 \%$ & $19.9 \%$ & $20.2 \%$ \\
\hline
\end{tabular}

Source: Authors' calculations from DYNASIM3.

1/ Lifetime earnings group includes both employer and employee premiums that are tax-exempt under cafeteria plans. Assumes proposal is effective on 1/1/2014. People are ranked by shared lifetime earnings within their birth cohort.

2/ Total tax includes employer and worker share of OASDI and HI tax plus federal income tax plus Medicare surtax. 


\section{Conclusions}

As Congress considers policy options to address the current and long-term deficits, options that expand the tax base and help reduce the growth in health care costs are likely to be considered. Two recent deficit reduction panels have proposed capping and ultimately eliminating the ESI exclusion. An immediate and full elimination of the ESI exclusion would increase federal income tax receipts, payroll tax receipts, and Medicare surtax receipts. But it would also increase Social Security benefits over time by increasing the earnings base. Social Security benefits decline at first because the increase in the earnings base reduces benefits for working beneficiaries between ages 62 and 66 who are subject to the retirement earnings test. Eventually, Social Security benefits increase, but the rise in benefits at first grows slowly because the rise in lifetime earnings only applies to those who start claiming or who are adding to their top 35 years of earnings after the effective date. But eventually the benefit increases grow more rapidly than the tax increases, reaching nearly 75 percent of increased OASDI taxes by 2080.

Because increased OASDI revenue exceeds increased benefits in every year, taxing ESI improves Social Security’s financing. But it does not eliminate the long-term OASDI deficit because promised benefits remain higher than OASDI taxes. Other reforms would still be needed to make Social Security solvent.

The combination of increased income and payroll taxes from including ESI in income is progressive at the bottom of the income distribution, but regressive at the top. The additional tax burden as a share of income increases between the bottom and middle quintiles of the distribution, but then it declines as income increases, falling very sharply at the top of the distribution. The change in benefits follows roughly the same pattern of distribution as the change in taxes, except that people at the bottom receive a relatively larger share of increased benefits than they pay in higher taxes. The distribution of the net tax increase (taxes less increased benefits), however, continues to be progressive at the bottom of the distribution and regressive at the top.

Overall, the present value of increased benefits including ESI in 2014 income offsets about 22 percent of the total tax increase, 57 percent of the payroll tax increase, and 72 percent 
of the increase in OASDI taxes. The ratio of increased taxes to increased benefits is higher for lower income than for upper income households, with households in the bottom quintile receiving additional benefits equal to slightly more than their increase in total taxes and about a third more than their increase in payroll taxes.

We caution that there is much imprecision in these estimates. The effects of including ESI in the tax base are very dependent on the future growth of health care costs and employer coverage rates, both of which are highly uncertain. The Affordable Care Act and uncertainty about how firms and individuals will respond to it adds additional imprecision to these projections.

Moreover, including ESI premiums in taxable income will induce additional behavioral changes. We have not modeled the effects of changes in the coverage and costs of health insurance plans due to the inclusion of ESI in taxable income. If including ESI in income causes employers to drop plans and people to shift to the federally-subsidized exchanges, the net gain to the federal budget will be less than we project. But OASDI receipts would increase by the same amount if employers substitute higher money wages for the reduced ESI benefits.

In spite of these qualifications, we believe our main findings are robust. The fiscal cost of increased OASDI benefits from including ESI in taxable wages will offset a growing share of the increased OASDI payroll tax receipts over time, leading to a smaller improvement in the OASDI trust fund balance than the higher revenues alone would generate. Increased OASDI benefits will offset a larger share of the higher taxes for low-income than for high-income households. And the net tax increase will hit middle income people the hardest, with both lower and upper-income households facing a smaller net tax increase as a share of their income. 


\section{References}

Burtless, Gary and Sveta Milusheva. 2012. "Effects of Employer Health Costs on the Trend and Distribution of Social Security-Taxable Wages.” Center for Retirement Research at Boston College. CRR WP 2012-11. April.

Burtless, Gary and Pavel Svaton. 2009. "Health Care, Health Insurance, and the Relative Income of the Elderly and Nonelderly." Center for Retirement Research at Boston College. CRR WP 2009-10. March.

Butrica, Barbara A., Richard W. Johnson, and Karen E. Smith. 2011. “The Potential Impact of the Great Recession on Future Retirement Incomes?” Urban Institute. Program on Retirement Policy. Discussion Paper 11-02. May.

Butrica, Barbara A., Karen E. Smith and C. Eugene Steuerle. 2006. "Working for a Good Retirement.” Urban Institute. The Retirement Project. Discussion Paper 06-03. May.

Clingman, Michael and Jeffrey Kunkel. 1992. “Average Wages for 1985-90 for Indexing Under the Social Security Act.” Social Security Bulletin. Vol 55, No, 4: 58-65.

Congressional Budget Office. 2013. The Distribution of Major Tax Expenditures in the Individual Income Tax System. May.

Favreault, Melissa M. and Karen E. Smith. 2004. “A Primer on the Dynamic Simulation of Income Model (DYNASIM3).” Discussion Paper, the Retirement Project, The Urban Institute.

Favreault, Melissa. 2009. "Rising Tides and Retirement: The Aggregate and Distributional Effects of Differential Wages Growth on Social Security.” Urban Institute. Retirement Policy Program. April.

Gruber, Jonathan. 2011. “The Tax Exclusion for Employer-Sponsored Health Insurance.” National Tax Journal 64 (2, Part 2): 511-530.

Gruber, Jonathan and Michael Lettau. 2004. “How Elastic is the Firm’s Demand for Health Insurance?” Journal of Public Economics 88(7-8): 1273-1294.

Gustman, Steinmeier, and Tabatabai. 2012. "The Growth in Social Security Benefits Among the Retirement-Age Population from Increases in the Cap on Covered Earnings.” Social Security Bulletin 72-2.

Helms, Robert. 2008. 'Tax Policy and the History of the Health Insurance Industry.” In Aaron, Henry J and Leonard E. Burman (eds.). Using Taxes to Reform Health Insurance: Pitfalls and Promises: 13-35. Brookings Institution Press: Washington, DC. 
Joint Committee on Taxation. 2013. "Estimates of Federal Tax Expenditures for Fiscal Years 2012-2017.” Prepared for the House Ways and Means Committee and the Senate Finance Committee. February 1. JCS 1-13.

Kaiser Family Foundation and Health Research Educational Trust. 2012. "Employer Health Benefits: 2012 Annual Survey.” Menlo Park, California. http://kaiserfamilyfoundation.files.wordpress.com/2013/03/8345-employer-healthbenefits-annual-survey-full-report-0912.pdf

Levine, Michael and Melinda Buntin. 2013. "Why Has Growth in Spending for Fee-for-Service Medicare Slowed?” Congressional Budget Office. Working Paper 2013-06.

Office of the Chief Actuary. "Provisions Affecting Coverage of Employment or Earnings.” At http://www.ssa.gov/OACT/solvency/provisions/coverage.html

Office of Management and Budget. 2013. Analytical Perspectives, Budget of the United States Government, Fiscal Year 2014. Washington, DC.

Rosenberg, Joseph. 2013. “Measuring Income for Distributional Analysis.” Washington, DC.: Urban-Brookings Tax Policy Center. July 25.

Smith, Karen. 2012. "Projection Methods Used in the Dynamic Simulation of Income Model (DYNASIM3).” Washington DC: The Urban Institute.

Smith, Karen E., Melissa Favreault, Caroline Ratcliffe, Barbara Butrica, Eric Toder, and Jon Bakija. 2007. “Final Report: Modeling Income in the Near Term 5”. Washington, DC.: Urban Institute.

Steuerle, Eugene, and Stephanie Rennane. 2011. "Social Security and Medicare Taxes and Benefits Over a Lifetime.” Washington, DC.: Urban Institute. http://www.urban.org/publications/412281.html.

Toder, Eric J., Benjamin H. Harris, and Katherine Lim. 2009. “Distributional Effects of Tax Expenditures.” Research Report/ Schwartz Center for Economic Policy Analysis, New School of Social Research, and Urban-Brookings Tax Policy Center. July 21. 


\section{RECENT WORKING PAPERS FROM THE CENTER FOR RETIREMENT RESEARCH AT BOSTON COLLEGE}

Lower-Income Individuals Without Pensions: Who Misses Out and Why? April Yanyuan Wu and Matthew S. Rutledge, March 2014

How Do Subjective Longevity Expectations Influence Retirement Plans?

Mashfiqur R. Khan, Matthew S. Rutledge, and April Yanyuan Wu, January 2014

Impact of the Great Recession on Retirement Trends in Industrialized Countries Gary Burtless and Barry P. Bosworth, December 2013

Does Household Debt Influence the Labor Supply and Benefit Claiming Decisions of Older Americans?

Barbara A. Butrica and Nadia S. Karamcheva, December 2013

Point of No Return: How Do Financial Resources Affect the Timing of Retirement After a Job Separation?

Matthew S. Rutledge, December 2013

The Medicaid Buy-In and Social Security Disability Insurance (DI) Beneficiaries: Lessons for the 2014 Medicaid Expansion and Proposals to Reform DI

Melissa McInerney, December 2013

Validating Longitudinal Earnings in Dynamic Microsimulation Models: The Role of Outliers

Melissa M. Favreault and Owen Haaga, September 2013

Housing in Retirement Across Countries

Makoto Nakajima and Irina A. Telyukova, August 2013

Can Benefits and Work Incentives Counseling Be a Path to Future Economic SelfSufficiency for SSI/SSDI Beneficiaries?

Zafar E. Nazarov, August 2013

How Do the Changing Labor Supply Behavior and Marriage Patterns of Women Affect Social Security Replacement Rates?

April Yanyuan Wu, Nadia S. Karamcheva, Alicia H. Munnell, Patrick Purcell, July 2013

Social Security and the 2001 Reform of the Railroad Retirement Program

Steven A. Sass, June 2013

All working papers are available on the Center for Retirement Research website (http://crr.bc.edu) and can be requested by e-mail (crr@bc.edu) or phone (617-552-1762). 